\title{
Investigating the provenance of iron bars from Les Saintes-Maries-de-la-Mer Roman shipwrecks (south-east France) with iron isotopes
}

\author{
Jean Milot $^{1,2}$ | Marie-Pierre Coustures ${ }^{2}$ | Franck Poitrasson ${ }^{1}$ (i) | \\ Sandrine Baron ${ }^{2}$ (1)
}

${ }^{1}$ Géosciences Environnement Toulouse, UMR 5563 Centre National de la Recherche Scientifique, Université de Toulouse, Institut de Recherches pour le Développement, Toulouse, France

${ }^{2}$ Travaux et Recherches Archéologiques sur les Cultures, les Espaces et les Sociétés, UMR 5608 Centre National de la Recherche Scientifique, Université de Toulouse, Toulouse, France

\section{Correspondence}

Jean Milot, Géosciences Environnement Toulouse, UMR 5563 Centre National de la Recherche Scientifique, Université de

Toulouse, Institut de Recherches pour le Développement, 14-16, avenue Edouard Belin, F-31400, Toulouse, France.

Email: jean.milot@ens-lyon.fr

Funding information

Federal University of Toulouse; Midi-Pyrénées Région

\begin{abstract}
Fe isotopes were used to determine the origin of iron bars from Les Saintes-Maries-de-la-Mer Roman shipwrecks, which was a major archaeological finding at the end of the 20th century in France. Their $\mathrm{Fe}$ isotope composition was measured by multi collectorinductively coupled plasma-mass spectrometry (MC-ICP-MS) after chemical Fe purification. The results allowed us to suggest provenances that were compared with those based on trace element analyses of slag inclusions. For most of the bars, we validate the provenance hypotheses previously proposed. Two bar groups originate from the Montagne Noire metallurgical district (south-west France), whereas a third group comes from another source, not clearly identified so far. In this context of Roman iron production, we argue for a non-spatially segmented production, where bars were manufactured close to smelting sites. Combined trace element and $\mathrm{Fe}$ isotope analyses on the same objects provide crucial information about the nature of their ore source. The elemental heterogeneity, positive $\mathrm{Eu}$ anomaly and $\mathrm{Fe}$ isotopic homogeneity of several bars were inherited from gossan-type ores, whereas the negative Eu anomaly and variable $\mathrm{Fe}$ isotopes signature of others most likely correspond to sedimentary iron ores. This study demonstrates that combined trace element and $\mathrm{Fe}$ isotopes analyses in a well-defined archaeological context is a promising approach for provenance studies of iron metals of archaeological interest.
\end{abstract}




\section{K E Y W O R D S}

Fe isotopes, Iron bars, MC-ICP-MS, Provenance, Roman iron trade

\section{INTRODUCTION}

The finding of several Roman shipwrecks offshore from the present city of Les Saintes-Mariesde-la-Mer (Bouches-du-Rhône department, south-east France) was a major archaeological discovery of the 1990s (e.g., Long, 1997; Long et al., 2002) (Figure 1). More than 20 shipwrecks dated between the first century BCE and the first century CE were studied along the successive excavation campaigns. Many of them contained from 20 to 150 tons of metal semi-products, such as lead and copper ingots (e.g., Baron et al., 2011; Trincherini et al., 2001), or large amount of iron bars depending on the wreck (e.g., Long, 1997; Long et al., 2002; Pagès et al., 2008, 2011). Because of the important quantity of archaeological iron artefacts, the diversity of their shapes and the presence of stamps on some of them (Coustures et al., 2006; Long et al., 2002), these iron bars from Les Saintes-Maries-de-la-Mer represent an exceptional open window onto the Roman iron trade in the Mediterranean area during this period.

The location of the shipwrecks, in front of one arm of the Rhône River (Petit Rhône) (Figure 1) may indicate that the ships were waiting for favourable meteorological conditions to carry their cargo of iron upstream into the interior of Gaul (Long \& Sintès, 2003). Both the chronology (from the first century BCE to the first century CE) and the important amount of iron found led historians and archaeologists to think that most of this metal was intended for the Roman army, first to conquer Gaul and then to defend the borders of the Roman Empire (Long et al., 2002). A few decades before the first ship laden with iron sank in the Mediterranean near Les Saintes-Maries-de-la-Mer, Romans came from Italy to the south of Gaul (first

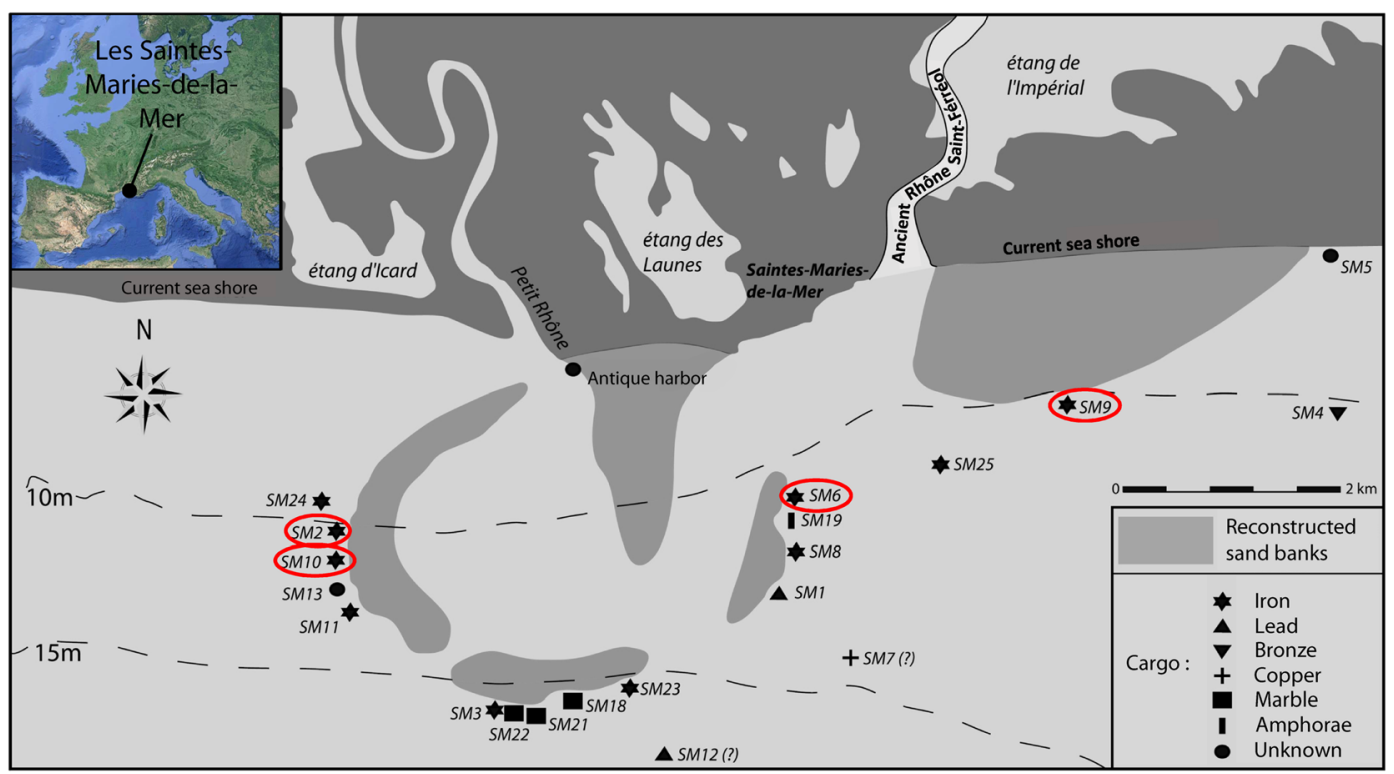

F I G U R E 1 Locations of Roman shipwrecks from Les Saintes-Maries-de-la-Mer, France, and descriptions of their cargos. The studied metallic irons are from the red-circled shipwreck locations (modified after Pagès et al., 2008) 
quarter of the first century $\mathrm{BCE}$ ) in a region called La Montagne Noire to set up what probably became the most important Roman iron-making centre of the period. Here, 110,000 tons of iron were produced in three centuries (Fabre et al., 2016). The relationship between this important region of production and the iron trade in the Mediterranean constitutes a major question to be addressed and solved.

\section{Elemental and isotopic methods for ancient iron tracing}

Besides archaeological investigations, geochemical tools have been developed to address specific questions concerning provenance determination or smelting process restitution. Tracing approaches are all based on conservative tracers along the metallurgical processes of iron production (e.g., Bachmann, 1982; Mangin, 2004; Pleiner, 2000, 2006). Provenance investigations mostly involve major and trace elements analyses of slag inclusions contained in iron artefacts, and comparison with the composition of potential ore sources (e.g., Blakelock et al., 2009; Coustures et al., 2003; Desaulty et al., 2009; Dillmann \& L'Héritier, 2007; Mameli et al., 2014). Along with elemental analyses, multivariate statistical treatments such as hierarchical clustering (HC), principal component analysis (PCA) or linear discriminant analysis (LDA) are commonly used to determine iron sources and reconstruct ancient networks of iron circulation (e.g., Bérard et al., 2020; Charlton et al., 2012; Disser et al., 2017; Hendrickson \& Leroy, 2020; Leroy et al., 2012, 2017; Stepanov et al., 2020). A major disadvantage of elemental analyses on slag inclusions resides in its destructive nature because it requires sectioning artefacts to acquire enough data on numerous slag inclusions for statistical treatment.

Several authors investigated the potential use of $\mathrm{Pb}, \mathrm{Sr}$ or Os radiogenic isotopes as tracing tools for ancient iron, with various levels of success (Brauns et al., 2013, 2020; Degryse et al., 2007; Dillmann et al., 2017; Liss et al., 2020; Schwab et al., 2006). Pb isotopes were found to be of limited interest because of their heterogeneity in iron ores due to low $\mathrm{Pb}$ and high $\mathrm{U}$ concentrations (Brauns et al., 2013; Schwab et al., 2006). Moreover, the chalcophile affinity of $\mathrm{Pb}$ involves its partition between the slag and metal, which may result in too low $\mathrm{Pb}$ concentration in Fe for precise isotopic measurements (Brauns et al., 2020). In addition to $\mathrm{Pb}$ isotopes, $\mathrm{Sr}$ was investigated as a tracer of ferrous objects (Degryse et al., 2007). Because of its lithophile affinity, Sr preferentially migrates into the slag during iron ore reduction. However, the initial $\mathrm{Sr}$ isotopic signature of ore may be substantially impacted by charcoal and the clay lining of the furnace during smelting since Sr may occur in notable concentrations in these components (Brauns et al., 2013, 2020).

More promising is the use of Os isotopes (Brauns et al., 2013, 2020; Dillmann et al., 2017; Liss et al., 2020). Os is a highly siderophile element that preferentially migrates into the metal phase during ore smelting with a strong enrichment from ore to metal and depletion into the slag which may provide information about metallurgical practices (Brauns et al., 2020). Moreover, the Os isotopic composition stays unchanged along the metallurgical processes of iron production, and shows significant variations from one deposit to another (Brauns et al.., 2013, 2020). For these reasons, Os isotopes are a good candidate as tracer of ancient iron, although the process involves complex techniques for sample extraction and isotopic measurements. As a result, literature on the natural Os isotopic variations in potential ore sources remains limited to date.

Recently, $\mathrm{Fe}$ isotopes were proposed as a new tool for ancient iron metals tracing (Milot et al., 2016). In nature, hydrothermal (e.g., Dauphas \& Rouxel, 2006; Moeller et al., 2014) and sedimentary processes involved in the formation of iron deposits (e.g., Frierdich et al., 2014b; Halverson et al., 2011; Johnson et al., 2008; Steinhoefel et al., 2009) induce Fe isotope fractionation. This leads to significant natural variability of $\mathrm{Fe}$ isotope compositions of iron ores, at the mining district scale, in different ores from a single mine or between different regions (e.g., Cheng 
et al., 2015; Horn et al., 2006; Markl et al., 2006; Wawryk \& Foden, 2015). This natural isotopic variability, combined with the absence of isotopic fractionation during the bloomery process, makes $\mathrm{Fe}$ isotope analysis a promising approach for provenance studies of ancient iron artefacts (Milot et al., 2016). This applies at least to cases where iron objects were produced from hydrothermal and sedimentary ores, since Rose et al. (2019) suggested that bog ores appear to be so heterogeneous in their $\mathrm{Fe}$ isotope compositions due to supergene processes that such signatures may not be discriminant enough. This matter will be discussed in more detail below.

\section{Objectives of this study}

Previous studies investigated the provenance of several iron bars from Les Saintes-Maries-dela-Mer by trace element analyses and tested the hypothesis of an origin from the Montagne Noire massif (Baron et al., 2011; Coustures et al., 2006). The present paper explores the origin of the same bars using Fe isotopes in order to validate the robustness of Fe isotopes as a pertinent tracer. This approach presents several advantages compared with elemental analyses of slag inclusions. First, only a few milligrams of non-corroded Fe are needed for Fe isotopes analysis, which greatly limits artefact deterioration (Milot et al., 2016). A second advantage is that the furnace wall's contribution in Fe is negligible due to the high Fe content of the ores relative to that of the refractory furnace lining. A third advantage is the observed Fe isotopic homogeneity of the metal produced (Milot et al., 2016) in comparison with the elemental variability of slag inclusions from the same object. Obviously, and as is often the case for all elemental and isotopic tracers, $\mathrm{Fe}$ isotope compositions may be overlapping between distinct iron-making regions. This cannot be a priori discarded. Hence, combining Fe isotopes analyses with other geochemical tracers, along with archaeological information, seems the most promising way to determine the geological sources of iron objects. Here we compare our new results of Fe isotopes analyses with those of trace elements from slag inclusions previously obtained from iron bars from Les Saintes-Maries-de-la-Mer, in a well-defined archaeological context, to refine provenance hypotheses. We also use this approach to provide information about the modalities of antic ore resources management at local or regional scales.

\section{MATERIALS AND METHODS}

\section{Iron bars from Les-Saintes-Maries-de-la-Mer: Typology and provenance assumptions}

A typology of six standardized shapes was established for iron bars from Les Saintes-Mariesde-la-Mer, mainly depending on their section geometry (Long, 1997; Long et al., 2002, 2005). Each shape can have a different length: short (C), medium (M) or long (L). Examples of these iron bars are shown on Figure 2. The detailed typology is given in Coustures et al. (2006). The 'EROTIS' and 'LEPIDI' stamps were identified and interpreted as corresponding to different iron-making workshops. The metal composition (iron or steel) may vary from a bar to another, or even within a single piece. These bars have been more or less refined (slag inclusion removal) and compacted, depending on the desired iron quality. Furthermore, some bars were formed by welding several iron pieces. Pagès et al. $(2008,2011)$ provide a detailed metallographic description of these bars.

The provenance of several bars from different shipwrecks was investigated through slag inclusions elemental analyses (Baron et al., 2011; Coustures et al., 2006). The hypothesis of a provenance from the Montagne Noire mining district was tested for two main reasons: (1) this massif was a major region of iron production during the Roman period, that is, from the first 


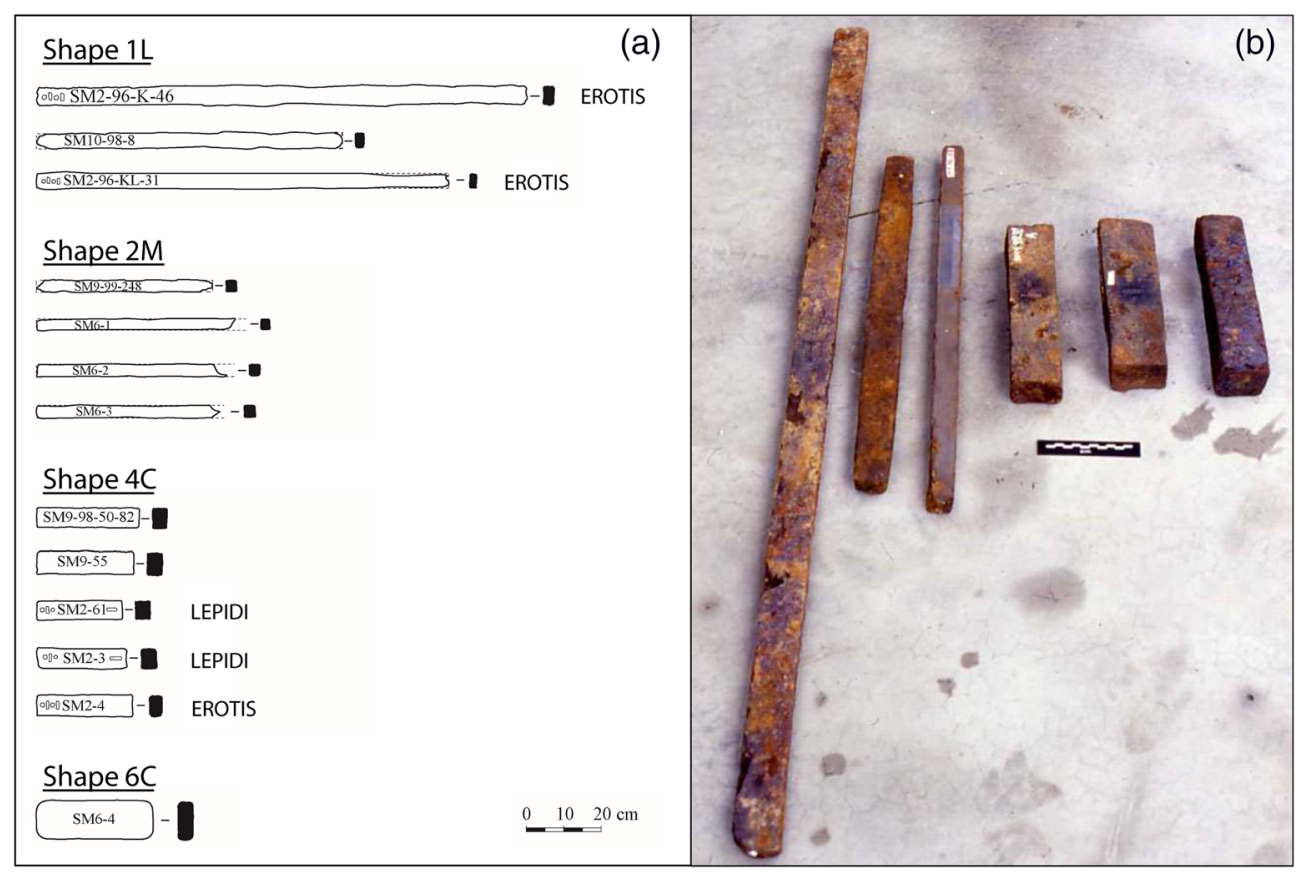

F I G U R E 2 (a) Types of iron bars from Les Saintes-Maries-de-la-Mer sampled in this study (after Baron et al., 2011); and (b) the different types of iron bars (from left to right): 1L, 1M, 2M and three 4C bars (photo: L. Long)

century BCE to the third century CE; and (2) this important iron production is contemporary with the dating of the wrecks that contained the iron bars (e.g., Domergue et al., 1993; Fabre et al., 2016). Baron et al. (2011) highlighted the variable trace element composition in the slag inclusions of these bars, sometimes related to a specific shape or stamp. For example, the iron bars with EROTIS and LEPIDI stamps show different elemental compositions, but both are included in the compositional range of archaeological ores and slags from the Montagne Noire. Moreover, all the studied bars of 2M shape (group 3) show similar trace element compositions (constant trace elements ratios), but clearly distinct from those of the Montagne Noire district. This led the authors to propose three groups of iron bars corresponding to different provenances (Figure 3). Group 1 contains bars suggested to come from the Montagne Noire (including EROTIS and LEPIDI stamped, and unstamped bars). Bars from group 2 may have another origin, with trace element compositions different from the Montagne Noire material for some ratios, as illustrated with the $\mathrm{Sm} / \mathrm{Eu}$ ratio in Figure 3. Iron bars from group 3 clearly show a distinct provenance (2M shape bars). These previous conclusions on bar provenance will form a basis against which we will compare Fe isotope signatures.

\section{Samples description}

We analysed the Fe isotope compositions of 12 out of the 13 bars previously studied for their trace element contents, spanning the range of the three groups previously described (see Table 1 for more details). Although one of these bars was not available anymore, we consider that our sampling is representative of the different groups. We also measured the Fe isotope composition of the SM2-96-K46 iron bar that exhibits an EROTIS stamp. Because of the small size of the slag inclusions contained in the metal, trace element analyses could not be performed on this 
(a)

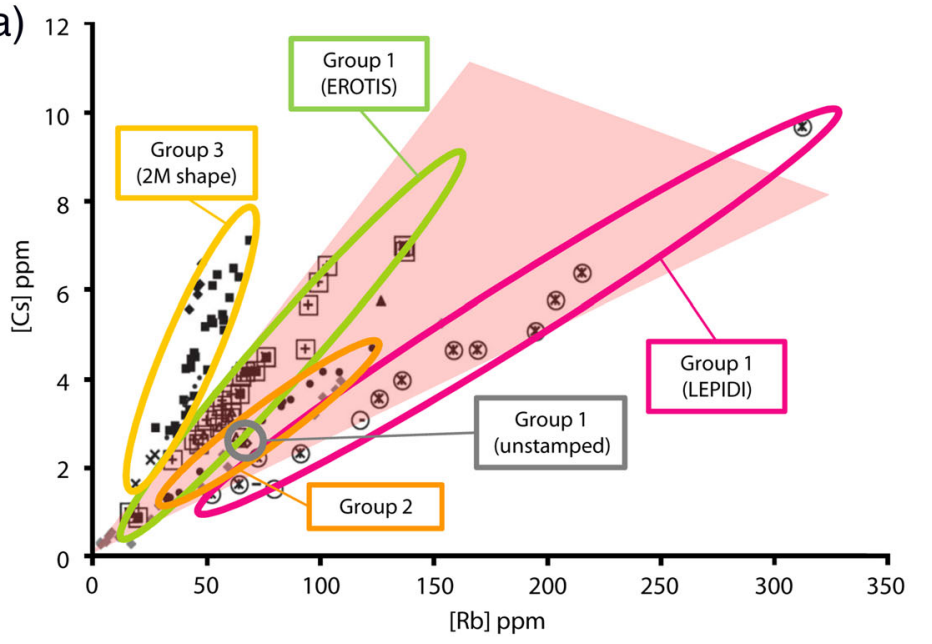

(b)

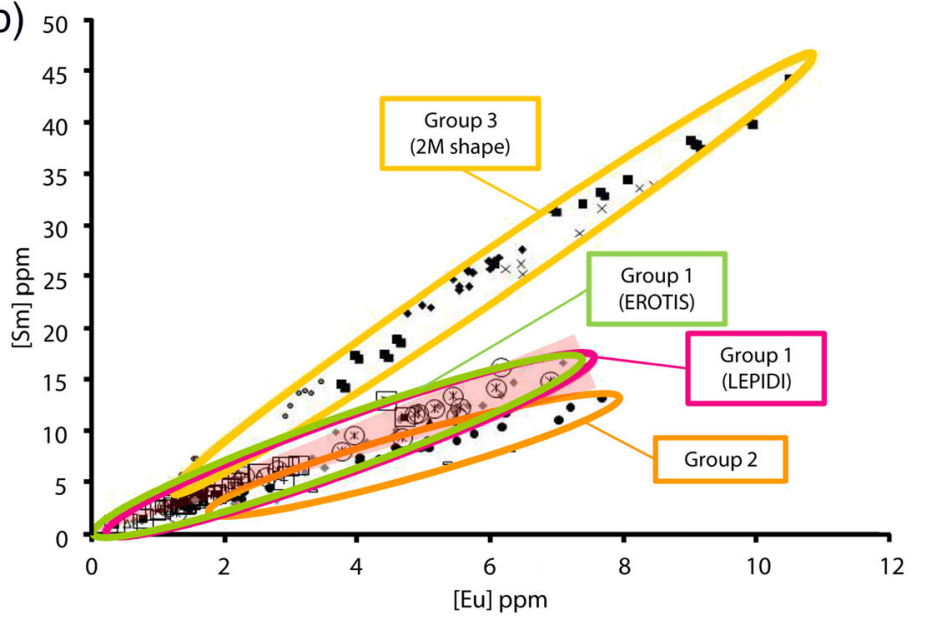

- Montagne Noire

- SM2-61*

- SM9-98-50-82*

SM9-99-248*

A $\mathrm{SM} 9-55^{*}$

* SM2-3*

SM6-4*

$+5 M 2-4^{*}$

$\times$ SM6-1*

SM6-3*

SM2-X

- SM6-2*

$\triangle \mathrm{SM} 2-96-\mathrm{KL} 31^{*}$

SM10-98-8*

EROTIS

- LEPIDI

F I G U R E 3 Trace element composition (a: Cs versus Rb; and b: Sm versus Eu) of slag inclusions from different bars from Les Saintes-Maries-de-la-Mer Roman shipwrecks in comparison with that of archaeological ores and slag samples from the Montagne noire mining district (red coloured area). According to Coustures et al. (2003), each constant trace element ratio corresponds to a specific provenance. ${ }^{*}$ Bars sampled for Fe isotope analyses (modified after Baron et al., 2011)

bar. As a result, it could not be included in any of the provenance groups determined by Baron et al. (2011). As previously indicated, the studied bars have different shapes (Figure 2a) and come from different shipwrecks (Figure 1). According to Pagès et al. (2008, 2011), 1L bars are, on average, made of steel with $0.4 \%$ carbon and systematically consist in an assemblage of two iron bloom pieces. The $4 \mathrm{C}$ bars are also made of steel, but are formed with only one iron bloom piece. They are generally less refined and compacted than $1 \mathrm{~L}$ ones. The $2 \mathrm{M}$ bars were a common semi-product in ancient times (Béziat et al., 2016b). They mainly consist of almost pure Fe with $0.02 \%$ carbon and formed from a single bloom piece moderately refined and compacted. The $6 \mathrm{C}$ bars are also made of almost pure $\mathrm{Fe}$ and formed from a single bloom piece correctly refined and compacted (Pagès et al., 2008). Except for two bars formed from a single bloom piece, we collected at least two and up to five samples on each of them (Table 1) in order to 
T A B L E 1 Description and location of the studied samples of Roman iron bars from Les Saintes-Maries-de-la-Mer, France

\begin{tabular}{|c|c|c|c|c|c|}
\hline Name & Shape* & $\begin{array}{l}\text { Provenance } \\
\text { group* }\end{array}$ & Stamp* & Date* & $\begin{array}{l}\text { Samples } \\
\text { collected }\end{array}$ \\
\hline SM2-96-KL31 & $1 \mathrm{~L}$ & Group 1 & EROTIS & $1^{\text {st }}$ quarter of the $1^{\text {st }}$ century $\mathrm{CE}$ & 5 \\
\hline SM2-4 & $4 \mathrm{C}$ & Group 1 & EROTIS & $1^{\text {st }}$ quarter of the $1^{\text {st }}$ century $\mathrm{CE}$ & 2 \\
\hline SM2-61 & $4 \mathrm{C}$ & Group 1 & LEPIDI & $1^{\text {st }}$ quarter of the $1^{\text {st }}$ century $\mathrm{CE}$ & 2 \\
\hline SM2-3 & $4 \mathrm{C}$ & Group 1 & LEPIDI & $1^{\text {st }}$ quarter of the $1^{\text {st }}$ century $\mathrm{CE}$ & 2 \\
\hline SM10-98-8 & $1 \mathrm{~L}$ & Group 1 & - & $1^{\text {st }}$ century CE & 2 \\
\hline SM9-98-50-82 & $4 \mathrm{C}$ & Group 2 & - & $\begin{array}{l}2^{\text {nd }} \text { quarter of the } 1^{\text {st }} \text { century } \\
\text { CE }\end{array}$ & 2 \\
\hline SM9-55 & $4 \mathrm{C}$ & Group 2 & - & $\begin{array}{l}2^{\text {nd }} \text { quarter of the } 1^{\text {st }} \text { century } \\
\text { CE }\end{array}$ & 1 \\
\hline SM6-4 & $6 \mathrm{C}$ & Group 2 & - & $2^{\text {nd }}$ half of the $1^{\text {st }}$ century $\mathrm{BCE}$ & 2 \\
\hline SM6-1 & $2 \mathrm{M}$ & Group 3 & - & $2^{\text {nd }}$ half of the $1^{\text {st }}$ century $\mathrm{BCE}$ & 2 \\
\hline SM6-2 & $2 \mathrm{M}$ & Group 3 & - & $2^{\text {nd }}$ half of the $1^{\text {st }}$ century $\mathrm{BCE}$ & 2 \\
\hline SM9-99-248 & $2 \mathrm{M}$ & Group 3 & - & $\begin{array}{l}2^{\text {nd }} \text { quarter of the } 1^{\text {st }} \text { century } \\
C E\end{array}$ & 1 \\
\hline SM6-3 & $2 \mathrm{M}$ & Group 3 & - & $2^{\text {nd }}$ half of the $1^{\text {st }}$ century $\mathrm{BCE}$ & 2 \\
\hline SM2-96-K46 & $1 \mathrm{~L}$ & n.a. & EROTIS & $1^{\text {st }}$ quarter of the $1^{\text {st }}$ century $\mathrm{CE}$ & 4 \\
\hline
\end{tabular}

*The shapes, provenance groups, stamps and dates of iron bars from Les Saintes-Maries-de-la-Mer were provided by Baron et al. (2011). The prefixes SM2, SM10, SM9 and SM6 correspond to the different Roman shipwrecks.

estimate their Fe isotopic homogeneity. In addition, we collected two samples of brownish corrosion of foliated structure formed on the surface of the bars in contact with seawater (marine corrosion in Table 2), and one sample of orange, fine-grained rust without specific structure formed on fresh metal during the storage of the bars under atmospheric conditions (atmospheric corrosion in Table 2).

\section{Analytical method}

The sampling and analytical methods used for the present study are detailed in Milot et al. (2016). Metal samples were collected by cutting little iron pieces (between 3 and $5 \mathrm{mg}$ ) with a diamond saw, according to the protocol established by Poitrasson et al. (2005) for iron meteorites. After acid digestion of the samples, Fe was separated from the rest of the matrix by anion-exchange chromatography. Fe isotope compositions were measured by high mass resolution multi-collector-inductively coupled plasma-mass spectrometry (MC-ICP-MS) at the GET laboratory (CNRS, Toulouse, France). The analytical method is detailed in Poitrasson and Freydier (2005) and Milot et al. (2016). The isotopes ${ }^{53} \mathrm{Cr},{ }^{60} \mathrm{Ni}$ and ${ }^{61} \mathrm{Ni}$ were measured besides ${ }^{54} \mathrm{Fe},{ }^{56} \mathrm{Fe}$ and ${ }^{57} \mathrm{Fe}$ for $\mathrm{Cr}$ isobaric interference correction on mass 54 and mass bias correction with $\mathrm{Ni}$ isotopes. Each sample was bracketed with reference material IRMM-14 in the analytical sequence. We corrected the mass bias by combining sample-standard bracketing and a daily regression method using the added $\mathrm{Ni}$ in every sample and standard. Additionally, we analysed an in-house hematite standard (ETH hematite) from Milhas, Pyrénées Mountains (southwestern France) every six samples for quality control. Each sample was analysed at least three times, and analytical uncertainties for individual samples are reported as 2 SE (standard errors) (Table 2). We expressed the Fe isotope compositions using the classic delta notation $\delta^{57} \mathrm{Fe}$ for 
T A B L E 2 Fe isotope compositions of the studied samples

\begin{tabular}{|c|c|c|c|c|c|c|}
\hline Sample & Description & $\delta^{57} \mathrm{Fe}(\%)$ & $2 S E$ & $\delta^{56} \mathrm{Fe}(\% 0)$ & $2 S E$ & $\begin{array}{l}\text { Number of } \\
\text { analyses }\end{array}$ \\
\hline \multicolumn{7}{|c|}{ Iron ore from the Montagne noire (les Martys) } \\
\hline $\mathrm{M} 2 *$ & Gossan ore & -0.490 & 0.081 & -0.343 & 0.159 & 6 \\
\hline M8* & Gossan ore & -0.453 & 0.075 & -0.290 & 0.273 & 3 \\
\hline M9* & Gossan ore & -0.384 & 0.136 & -0.238 & 0.154 & 6 \\
\hline M11* & Gossan ore & -0.414 & 0.072 & -0.269 & 0.076 & 6 \\
\hline
\end{tabular}

Roman iron bars from Les Saintes-Maries-de-la-Mer

Group 1

$\begin{array}{lllllll}\text { SM2-96-KL31a } & \text { Metallic iron } & -0.293 & 0.118 & -0.192 & 0.083 & 6 \\ \text { SM2-96-KL31b } & \text { Metallic iron } & -0.283 & 0.145 & -0.198 & 0.087 & 6 \\ \text { SM2-96-KL31c } & \text { Marine corrosion } & -0.133 & 0.075 & -0.080 & 0.052 & 3 \\ \text { SM2-96-KL31d } & \text { Metallic iron } & -0.323 & 0.068 & -0.239 & 0.027 & 3 \\ \text { SM2-96-KL31e } & \text { Metallic iron } & -0.302 & 0.051 & -0.223 & 0.079 & 3 \\ \text { SM2-4a } & \text { Metallic iron } & -0.245 & 0.086 & -0.152 & 0.139 & 9 \\ \text { SM2-4b } & \text { Metallic iron } & -0.330 & 0.027 & -0.250 & 0.069 & 3 \\ \text { SM2-61a* } & \text { Metallic iron } & -0.327 & 0.082 & -0.186 & 0.106 & 3 \\ \text { SM2-61b* } & \text { Metallic iron } & -0.362 & 0.077 & -0.260 & 0.058 & 6 \\ \text { SM2-3a* } & \text { Metallic iron } & -0.388 & 0.111 & -0.264 & 0.076 & 6 \\ \text { SM2-3b* } & \text { Metallic iron } & -0.420 & 0.072 & -0.287 & 0.042 & 6 \\ \text { SM10-98-8a } & \text { Metallic iron } & -0.333 & 0.122 & -0.202 & 0.248 & 6 \\ \text { SM10-98-8b } & \text { Metallic iron } & -0.289 & 0.160 & -0.150 & 0.324 & 3\end{array}$

\section{Group 2}

SM9-98-50-82a

SM9-98-50-82b

Metallic iron

$-0.254$

$0.103-0.166$

0.0716

SM9-55

SM6-4a

Metallic iron

$-0.252$

0.100

$-0.149$

0.2576

Metallic iron

$-0.275$

0.096

$-0.175$

$0.152 \quad 6$

SM6-4b

Metallic iron

$-0.259$

$0.013-0.180$

0.0243

$-0.309$

$0.117-0.208$

0.0626

Group 3

SM6-1a

SM6-1b

SM6-2a

SM6-2b

SM9-99-248

SM6-3a

SM6-3b

Metallic iron

$$
-1.329
$$

$0.080-0.905$

0.0393

$-1.340$

$0.181-0.912$

0.1159

Metallic iron

$-0.773$

$0.062-0.527$

0.0556

Metallic iron

$-0.797$

$0.100-0.555$

0.0326

$-0.621$

$0.125-0.384$

$0.152 \quad 6$

Metallic iron

$-0.369$

$0.116-0.247$

$0.068 \quad 8$

$-0.311$

$0.079-0.213$

$0.025 \quad 3$

Unclassified

SM2-96-K46a

SM2-96-K46b

Metallic iron

$-0.305$

$0.112-0.206$

$0.159 \quad 6$

SM2-96-K46c

Marine corrosion

$-0.738$

$0.083-0.506$

$0.173 \quad 10$

SM2-96-K46d

Atmospheric corrosion

$-0.271$

$0.122-0.188$

$0.097 \quad 6$

Metallic iron

$-0.277$

$0.088 \quad-0.179$

0.0729

*Published in Milot et al. (2016). For a clearer presentation, terminations of the sample names (1) and (2) in Milot et al. were replaced by ' $a$ ' and ' $b$ ' in this study. These letters correspond to different samplings from the same iron bar. Samples of the long bars SM2-96-KL31, SM10-98-8 and SM2-96-K46 (type 1L) were collected on each part assembled by welding. See the text for details on bar classification. 
the ${ }^{57} \mathrm{Fe} /{ }^{54} \mathrm{Fe}$ ratio (\%o), relative to IRMM-14 reference material. Along the successive analytical sequences spanning over 24 months, the ETH hematite standard from Milhas was analysed 263 times. According to the method developed by Poitrasson and Freydier (2005), hematite measurements should be pooled by groups of six to estimate the long-term reproducibility of our analyses. This yielded a $\delta^{57} \mathrm{Fe}=0.760 \pm 0.069 \%$ and $\delta^{56} \mathrm{Fe}=0.515 \pm 0.076 \%$ with uncertainties reported as $2 \mathrm{SD}$ (standard deviation). This compares well with previous measurements from, for example, Mulholland et al. (2015) and Sossi et al. (2016) yielding $\delta^{57}$ $\mathrm{Fe}=0.782 \pm 0.081 \%$ (2 SD) and $\delta^{57} \mathrm{Fe}=0.753 \pm 0.094 \%$ (2 SE), respectively

\section{RESULTS}

The Fe isotope compositions of the iron bars from Les Saintes-Maries-de-la-Mer are presented in Table 2 and Figure 4. Except for bars SM9-55 and SM9-99-248 from which only one sample was collected, each bar shows a homogeneous $\delta^{57} \mathrm{Fe}$ within analytical uncertainties (Figure 4). However, Student's $t$-tests show that the two samples (SM2-96-KL31c and SM2-96-K46b) from bars having undergone marine corrosion display $\mathrm{Fe}$ isotope compositions $\left(\delta^{57}\right.$ $\mathrm{Fe}=-0.133 \pm 0.075 \%$ and $-0.738 \pm 0.083 \%$, respectively) significantly different to those of non-corroded portions from the same bars. On the other hand, the sample that underwent atmospheric corrosion, SM2-96-K46c, has an isotopic composition undistinguishable from those of non-corroded portions of this bar. As stated above, the three groups of bars mentioned below were determined according to their trace element composition of slag inclusions (Figure 3), reported by Baron et al. (2011). Excluding the marine corroded sample SM2-96-KL31c, iron bars from group 1 have Fe isotope compositions between $-0.420 \%$ and $-0.245 \%$. The bars from the group 2 have Fe isotope compositions between $-0.309 \%$ and $-0.252 \%$. These composition ranges are undistinguishable from iron gossans from the Montagne Noire (Figure 4). In contrast to their constant $\mathrm{Cs} / \mathrm{Rb}$ and $\mathrm{Sm} / \mathrm{Eu}$ ratios (Figure 3), each four iron bars from group 3 has its own Fe isotope composition, although sometime partly overlapping (Figure 4). Bars from this group cover a total compositional range from $-1.340 \%$ o to $-0.311 \%$. We also note that the Fe isotope compositions of SM9-99-248 and SM6-3 bars from group 3 are partly or completely included in the range of ores from the Montagne Noire, within analytical uncertainties. In contrast, the two other bars from group 3, SM6-1 and SM6-2, have $\delta^{57} \mathrm{Fe}$ values clearly outside this range (Table 2 and Figure 4).

\section{DISCUSSION}

\section{Fe isotopes for ore sources determination}

A crucial point for the use of $\mathrm{Fe}$ isotopes to trace ancient metals is the isotopic variability of the ore sources. Many authors investigated the fractionation processes of Fe isotopes in magmatic and hydrothermal systems (e.g., Bilenker et al., 2016; Gagnevin et al., 2012; Günther et al., 2017; Sun et al., 2013; Wang et al., 2011; Zhao et al., 2019) or in sedimentary iron ores (e.g., Busigny \& Dauphas, 2007; Czaja et al., 2013; Halverson et al., 2011; Rose et al., 2019). In high-temperature magmatic and hydrothermal systems, Fe isotope fractionation may occur between early crystallizing $\mathrm{Fe}$ minerals and the residual magma or hydrothermal fluid (e.g., Gagnevin et al., 2012; Wang et al., 2011, 2015; Zhao et al., 2019). Subsequent alteration of these deposits may also generate Fe isotopic fractionation (e.g., Fernandez \& Borrok, 2009; $\mathrm{Zhu}$ et al., 2018). For example, Wang et al. (2011) reported an isotopic range $\left(\Delta^{57} \mathrm{Fe}\right)$ of $0.740 \%$ in magnetite from the skarn-type Xinqiao deposit in China. We can also cite the ranges of $0.970 \%$ and $0.700 \%$ measured in magnetites from the Zhibo and Chagangnuoer skarn 


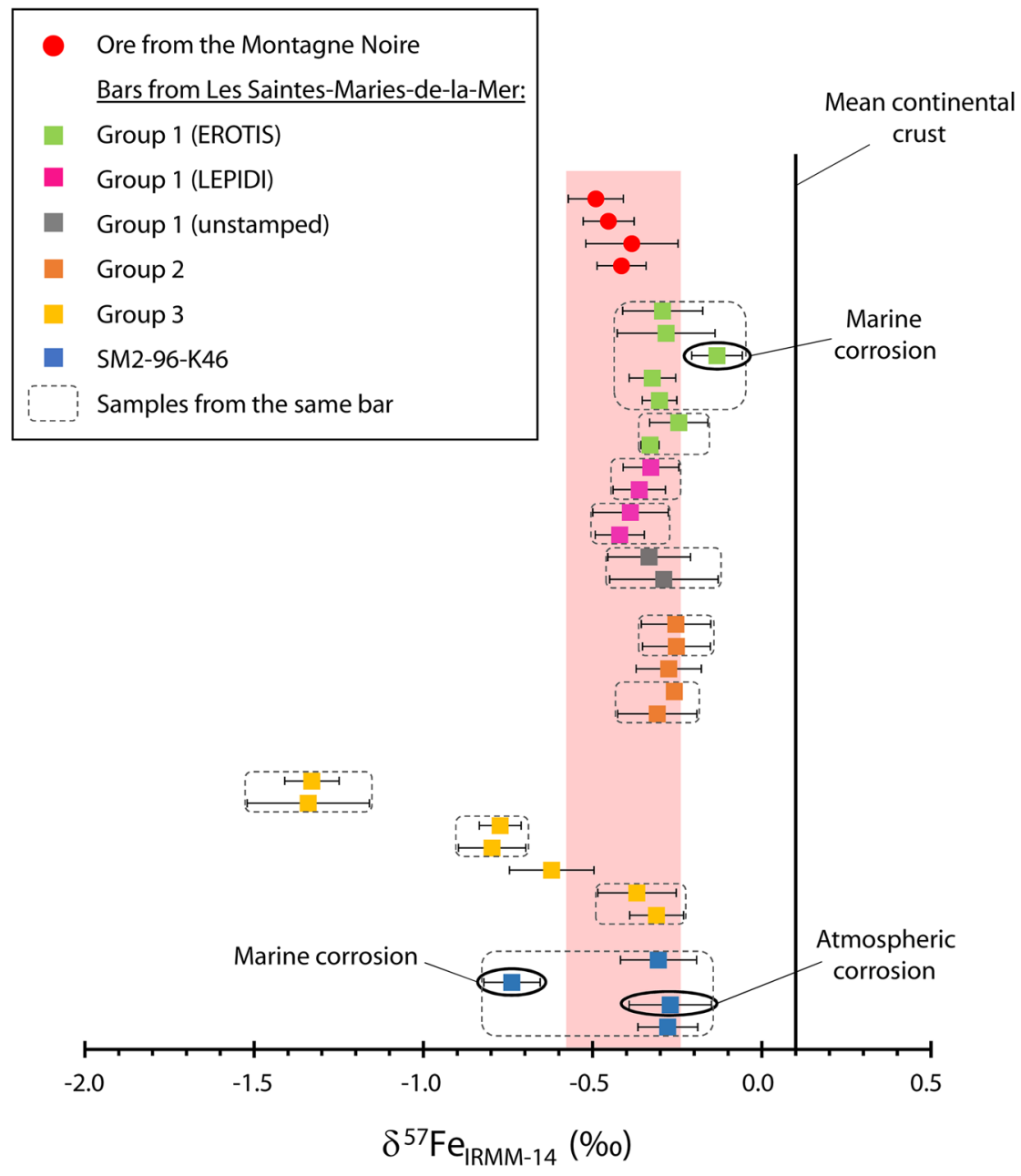

F I G U R E 4 Fe isotope composition of iron bars from Les Saintes-Maries-de-la-Mer Roman shipwrecks compared with that of ore from the Montagne noire mining district (south-western France), expressed as $\delta^{57} \mathrm{Fe}(\% 0)$ relative to the IRMM-14 Fe isotopic reference material. The different groups are defined according to provenance assumptions proposed by Baron et al. (2011) from slag inclusions elemental analyses. See the text for more detailed information. The line with $\delta^{57} \mathrm{Fe}=0.1 \%$ reported for the reference corresponds to the mean Fe isotope composition of the Earth's crust (Poitrasson, 2006). Uncertainties are reported as 2 SE (standard errors). From top to bottom, Isotopic composition of bars are plotted in the same order as listed in Table 2

deposits, respectively (Günther et al., 2017). Also, some other examples are the range of 0.795\% observed in magnetite from the Los Colorados deposit in Chile (Bilenker et al., 2016), or that of $0.410 \%$ ound in magnetite and hematite-rich iron ores of magmatic origin from the Bayan Obo deposit in China (Sun et al., 2013). Finally, hematite precipitation and dissolution experiments under hydrothermal conditions conducted by Saunier et al. (2011) showed fractionation between fluids and hematite of $0.5 \%$ at most. Overall, the extent of high-temperature $\mathrm{Fe}$ isotope fractionation is much lower than the large isotopic variability, typically $>1 \%$, found in sedimentary iron ores formed at low temperature such as banded iron formation (BIF) (e.g., Czaja et al., 2013; Halverson et al., 2011) or iron concretions (Busigny \& Dauphas, 2007). Recently, Rose et al. (2019) pointed out the extreme Fe isotopic heterogeneity of about 4\%o in 
bog iron ores exploited for ancient iron production in Northern Europe and questioned the pertinence of the use of Fe isotopes for ancient Fe metal tracing. However, Rose et al. (2019) missed two important points in their reasoning to make it widely applicable for archaeological $\mathrm{Fe}$ metal source provenance studies.

First, they elaborate their opinion on a very specific type of iron ore: ancient peat bogs. These iron bog ores have a strong Fe isotopic heterogeneity, and this favours important overlapping with the isotopic composition of many other iron ores worldwide. This scepticism is shared by Stephens et al. (2021) in their review of the use of stable isotopes in archaeological research. We emphasize here that bog iron formations only occur in glaciated regions of the Northern Hemisphere (e.g., Robb, 2013), and the limitation pointed out for these ores does not necessarily concern other areas. Although ferruginous crust (alios ores) formed quite similarly to bog iron may have been sporadically mined in ancient Gaul (e.g., Coustures et al., 2014), the vast majority of iron ores exploited in the Roman world were Fe oxides and oxyhydroxides from gossans, both of hydrothermal or magmatic origin, such as hematite, magnetite and goethite (e.g., Benvenuti et al., 2013; Béziat et al., 2016b; Degryse et al., 2007; Pleiner, 2000), whose Fe isotopic variability is much limited as previously discussed.

Second, and above all, Rose et al. (2019) totally ignored the crucial importance of the archaeological context that should be taken into account for every provenance study. This means that the archaeological hypothesis guides the choice of the potential geographical areas concerned by the issue. We do not randomly take the worldwide databases available in the literature to discover a possible ore source of the iron artefact studied. In the case of Roman iron production in the Montagne Noire, ancient miners only selected a particular type of ore located nearby. They used carbonate-derived gossans and not the sulphide-derived ones (e.g., Domergue et al., 1993; Fabre et al., 2016). Moreover, and as emphasized by Milot et al. (2016), the ore was processed (i.e., roasted and crushed, besides sorting) before its use for iron production (Baron et al., 2011; Coustures et al., 2006). This led to a significant reduction of the Fe isotope variation of the starting ore material (Milot et al., 2016) by comparison with that found at the mineral-scale in natural iron ore deposits.

We also recall that overlapping compositions due to ore sources variability are common and were observed for every elemental and isotopic tracers (e.g., Artioli et al., 2020; Charlton, 2015). Hence, and in contrast to Rose et al. (2019), we consider that the pertinence of $\mathrm{Fe}$ isotopes for ancient metal tracing cannot be simply dismissed by comparing directly the composition of archaeological materials with that of unrelated and/or unprocessed ore sources. Rather, they must be examined in the frame of a well-defined geological and archaeological context since in the present case, the ore selection and processing led to a reduction of the naturally occurring Fe isotope range of the ore (Milot et al., 2016). For this reason, provenance studies should consist of testing provenance hypotheses based on archaeological and historical arguments, and the combination of several tracers is the most promising approach to validate or refute these assumptions in this archaeological context.

\section{Corroded iron samples}

Two of the three samples of corroded iron analysed in this study show distinct Fe isotope compositions (Figure 4). Contrary to SM2-96-KL31c and SM2-96-K46b that underwent marine corrosion, sample SM2-96-K46c was corroded under atmospheric conditions after sample cutting and room storage. Its $\mathrm{Fe}$ isotope composition of $-0.271 \pm 0.122 \%$ is similar to that of non-corroded iron samples from the same bar. This is explained by the lack of Fe loss by exchange with the atmosphere at room temperature during the corrosion process. Hence, no Fe isotope fractionation could occur during atmospheric corrosion of this sample. On the other hand, we observe opposite trends of $\mathrm{Fe}$ isotope fractionation of the two marine corroded 
samples relative to their pristine counterparts (Figure 4). The composition of SM2-96-KL31c enriched in heavy $\mathrm{Fe}$ isotope is expected since it is widely admitted that Fe oxidation favour heavier isotopic compositions (e.g., Frierdich et al., 2014a; Johnson et al., 2002), assuming that the isotopically light Fe was leached by seawater. In this scenario, the clearly lighter isotopic composition of SM2-96-K46b relative to non-corroded samples from the same bar is surprising. A possible explanation could be that this weathered marine crust would rather represent isotopically light Fe leached out from other portions of the bar or from other bars undergoing corrosion from the same wreck cargo that re-precipitated there. Further detailed in situ Fe isotope measurements, combined with chemical, mineralogical and metallurgical investigations, would be required to go further into the interpretation of these results. Overall, this illustrates the need to analyse iron samples not corroded by seawater for archaeological provenance studies. Rose et al. (2020) reached an opposite conclusion and argued for the absence of Fe isotope fractionation during the corrosion of iron artefacts. However, we consider that these authors most likely missed significant fractionation between corroded and not corroded samples because of insufficiently precise and accurate Fe isotope measurements. They measured the Fe isotope composition of several samples only once or twice, and the reported uncertainties of each sample were estimated from the external reproducibility based on repeated measurements of the IRMM-14 bracketing reference material, which is a pure Fe solution that did not require prior purification chemistry as regular samples do. Moreover, they did not report Fe isotope determinations of (geological) reference materials, as done here and in our previous work (Milot et al., 2016) to assess data accuracy. The analytical uncertainties reported by Rose et al. (2020) are thus most likely underestimated, hence the reason why they could not see the small isotopic effect imparted by iron corrosion, although the way corrosion was sampled and compared with non-corroded iron bars could be another explanation.

\section{Provenance of the iron bars from Les Saintes-Maries-de-la-Mer}

\section{Bars from group 1}

Except for the marine corroded sample SM2-96-KL31c, all the bars from group 1 (all found in the SM2 shipwreck) have similar Fe isotope compositions, included in the compositional range of archaeological ore from Le Domaine des Forges (Les Martys site) in the Montagne Noire massif (Figure 4). This confirms the provenance from this district suggested by trace element analysis (Baron et al., 2011). Contrary to Cs and Rb concentrations in slag inclusions, $\mathrm{Fe}$ isotope compositions of iron bars are not discriminant between EROTIS and LEPIDI stamped bars.

A probable explanation for these results is that the Fe isotope homogeneity and elemental heterogeneity of these bars are inherited characteristics from the iron ore of the Montagne Noire. Gossans from this mining district result from the supergene weathering of hydrothermal veins of carbonates or sulphides primary ores (e.g., Béziat et al., 2016b; Milot et al., 2016). However, the $\delta^{57} \mathrm{Fe}$ of carbonate-derived gossans selected by Roman smelters strictly differs from that of sulphide-derived gossans from the surrounding Salsigne mine (Milot et al., 2016) (Figure 5). The narrow Fe isotope signature of group 1 bars reflects that of carbonate-derived ores (Figure 4) and indicates their common origin. $\mathrm{Fe}$ isotopes can therefore help to discriminate metal sources at an interregional scale. On the other hand, Baron et al. (2011) highlighted the wide elemental heterogeneity of archaeological ores from the Montagne Noire, despite the Roman selection, relative to available resources. This is also despite metallurgical processes, which tend to homogenize this elemental variability. Therefore, the elemental composition of reduction slags and slag inclusions in the metal correspond to the averaged composition of the ore load introduced into 


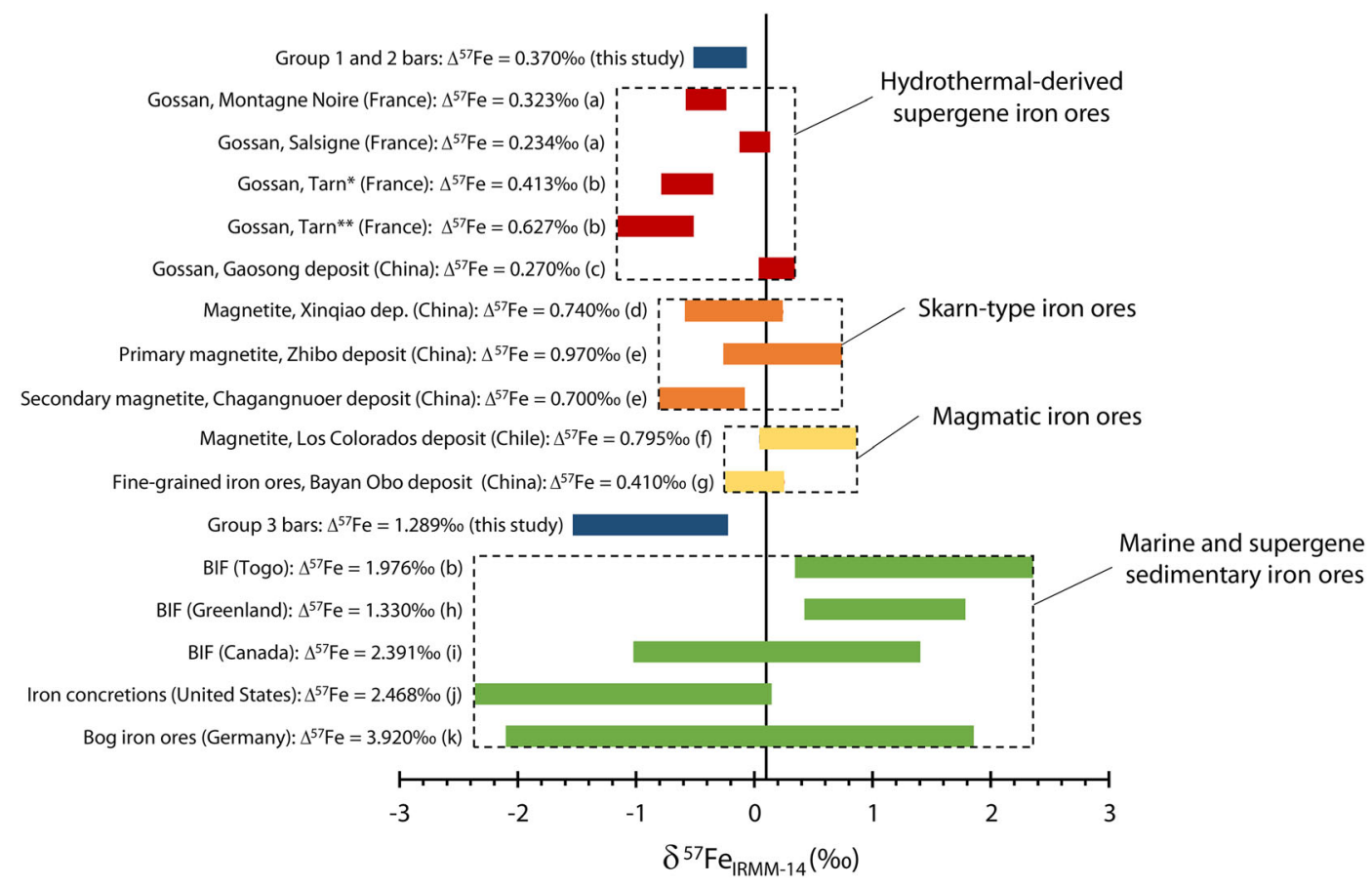

F I G U R E 5 Variation ranges of $\mathrm{Fe}$ isotope composition $\left(\Delta^{57} \mathrm{Fe}, \%\right.$ o $)$ of iron bars from groups $1-3$ compared with those of examples iron ores from the literature and with the mean continental Earth crust $\left(\delta^{57} \mathrm{Fe}=0.1 \%\right.$, according to Poitrasson, 2006). Shown are Fe isotope variation ranges of iron ores from the *Ambialet and **Crespin sectors (Tarn department, south-west France) (see Milot, 2016, for more details). Reported data are from (a) Milot et al. (2016), (b) Milot (2016), (c) Cheng et al. (2015), (d) Wang et al. (2011), (e) Günther et al. (2017), (f) Bilenker et al. (2016), (g) Sun et al. (2013), (h) Czaja et al. (2013), (i) Halverson et al. (2011), (j) Busigny and Dauphas (2007) and (k) Rose et al. (2019). Except for the Montagne noire, the reported $\delta^{57} \mathrm{Fe}$ values and ranges (expressed as $\Delta^{57} \mathrm{Fe}$, i.e., the difference between the two most extreme $\delta^{57} \mathrm{Fe}$ values of a given ore) are extremes since ore selection and treatment by ancient metallurgists tend to homogenize and therefore reduce the natural ore isotopic variability at a given archaeological site before iron metal production (for details, see the text and Milot et al., 2016)

the furnace (Béziat et al., 2016b; Coustures et al., 2007). Hence, distinct elemental ratios, each included in the elemental range of the Montagne Noire, correspond to the signature of several smelting workshops of this mining district (EROTIS and LEPIDI workshops for bars from group 1 in Figure 3). Trace elements thus provide relevant information about the organization of iron exploitation and ore supply within a region of iron production. This illustrates the complementarity of uncorrelated Fe isotopes and trace elements for metal source investigation at different scales.

\section{Bars from group 2}

Iron bars from the group 2 have $\mathrm{Fe}$ isotope compositions similar to those of group 1 bars (Figure 4). They are also included in the isotopic range of archaeological ores from the Montagne Noire, which argues for a provenance from this mining district. Baron et al. (2011) mentioned a possible alternative provenance for bars from group 2 because their slag inclusion $\mathrm{Sm} / \mathrm{Eu}$ ratio slightly differs from that of materials from the Montagne Noire district (Figure 3). However, they concluded that these elemental differences may be not significant and further analyses should be performed to better constrain their composition. Moreover, they advised 
that the entire range of elemental composition of materials from the Montagne Noire may not yet have been uncovered. According to our Fe isotopic results, we suggest that these bars are from the Montagne Noire.

\section{Bars from group 3}

Several bars from group 3 have $\delta^{57} \mathrm{Fe}$ clearly distinct from the compositional range of the Montagne Noire ore (SM6-1 and SM6-2) (Table 2 and Figure 4). This is consistent with the hypothesis of a provenance different from this district, as suggested by Baron et al. (2011) according to their trace element compositions (Figure 3). However, the Fe isotope composition of both SM9-99-248 and SM6-3 bars is partly or totally overlapping with that of the Montagne Noire (Figure 4). A different provenance for these last two bars thus cannot be validated in the light of their $\mathrm{Fe}$ isotope results. They may reflect overlapping isotopic compositions between the Montagne Noire district and another area of iron production not yet identified.

Except for SM9-99-248 and SM6-3, bars from group 3 have distinct Fe isotope composition (Table 2 and Figure 4), which argues for a different origin. This hypothesis is plausible since $2 \mathrm{M}$ bars' shape and size, to which these group 3 bars belong ( Table 1), were very common in the antique period (Béziat et al., 2016b). However, this hypothesis is not consistent with the constant trace elemental ratio highlighted by Baron et al. (2011) that support a common provenance for all group 3 bars. The rare earth elements (REE) composition of slag inclusions in iron bars can provide information about the nature of their ore source. In particular, previous studies revealed that an important positive Eu anomaly $\left(\mathrm{Eu} / \mathrm{Eu}^{*}>1\right)$ is characteristic of hydrothermal deposits and is transmitted to hydrothermal-derived gossans (e.g., Leybourne et al., 2006), whereas their derivative supergene sediments are Eu-depleted (Leybourne \& Johannesson, 2008). Additionally, other authors investigated REE compositions of sedimentary $\mathrm{BIF}$ and concluded that positive Eu anomalies in BIF are due to hydrothermal inputs in seawater where they formed (e.g., Danielson et al., 1992; Hu et al., 2020), and drastically decreased in post-2.7 Ga banded formation (Kato et al., 2006). On the other hand, negative Eu anomalies $\left(\mathrm{Eu} / \mathrm{Eu}^{*}<1\right)$ were measured in oolithic iron ores (Baioumy et al., 2017). The high $\mathrm{Sm} / \mathrm{Eu}$ ratio of group 3 bars, in comparison with hydrothermal gossan from the Montagne Noire (Figure 3), indicates a lower Eu content and argues for a sedimentary ore source for these bars. Simple calculation of $\mathrm{Eu}$ anomalies $\left[\mathrm{Eu} / \mathrm{Eu}^{*}=\mathrm{Eu} /(\mathrm{Sm} \times \mathrm{Gd})^{1 / 2}\right]$ from trace element data provided by Baron et al. (2011) and comparison with those of different types of ores from the literature strongly reinforce this hypothesis (Figure 6). The Eu anomalies of slag inclusions from both groups 1 and 2, normalized to chondrite composition (McDonough \& Sun, 1995), are positive (1.26-1.97) and similar to those of gossans from the Montagne Noire (calculated from trace element data reported by Coustures et al., 2003) (Figure 6). This is consistent with a hydrothermalderived ore source and strengthens the assumption of a provenance from the Montagne Noire for these bars. In contrast, those of bars from group 3 are negative $(0.64-0.70)$, which indicates a sedimentary iron source. The loss of Eu in rock is linked to the weathering of Eu-bearing plagioclases and correlated to alteration intensity (e.g., Babechuk et al., 2014; Ma et al., 2011). Hence, the negative $\mathrm{Eu}$ anomalies likely result from the leaching of a primary iron source and subsequent deposition of sedimentary iron ore from which group 3 bars originate. A source of Eu-depleted marine sedimentary oolithic iron for these bars could be another explanation.

The heterogeneous $\delta^{57} \mathrm{Fe}$ of bars from group 3 is not in contradiction with the assumption of a sedimentary origin. Comparable, or even larger, variations of Fe isotope compositions were indeed measured in iron ore sources worldwide, such as banded iron formations (e.g., Czaja et al., 2013; Halverson et al., 2011; Milot, 2016), iron concretions (Busigny \& Dauphas, 2007) or bog iron ores (Rose et al., 2019) (Figure 5). If the biotic or abiotic origin of this isotopic variability is still a matter of debate (e.g., Bullen et al., 2001; Halverson 


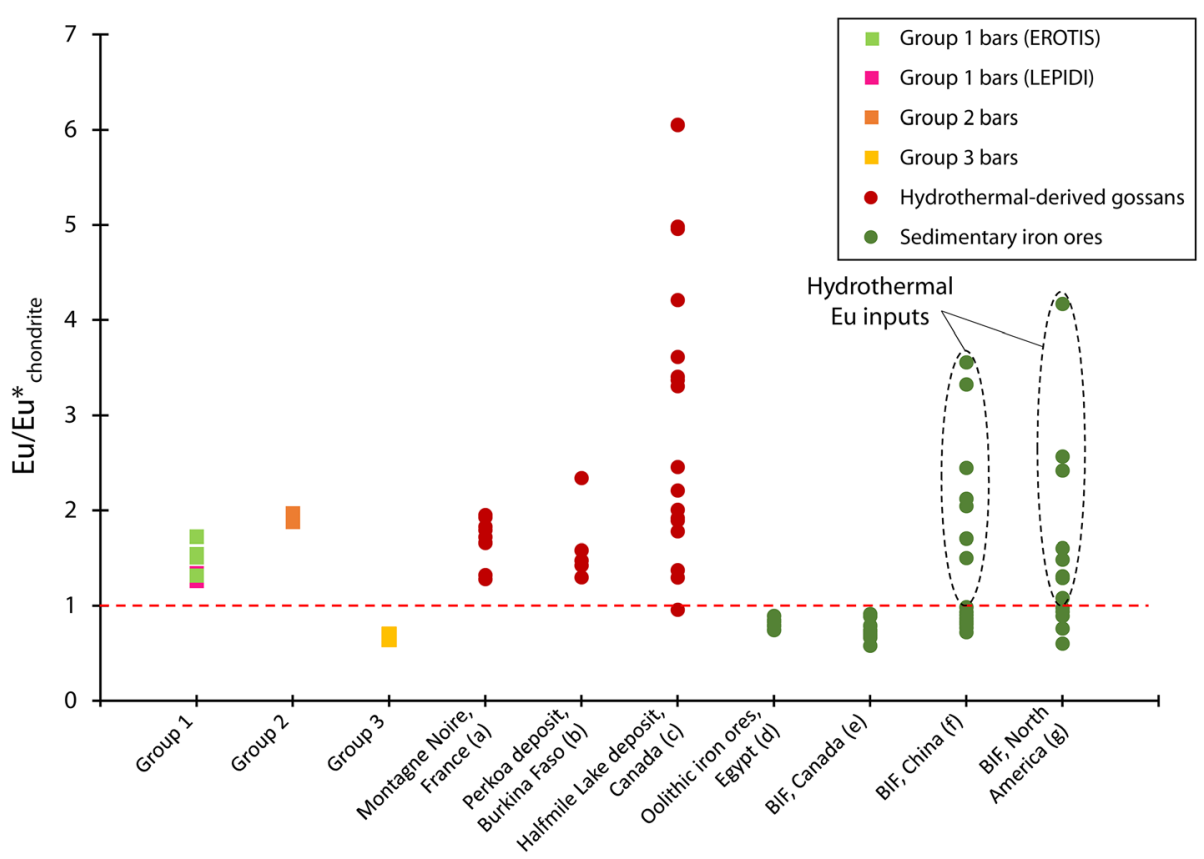

F I G U R E 6 Eu anomalies of iron bars from groups 1-3 compared with those of different types of iron ores from the literature. Eu anomalies were calculated as $\mathrm{Eu} / \mathrm{Eu}^{*}{ }_{\text {chondrite }}=\mathrm{Eu} /(\mathrm{Sm} \times \mathrm{Gd})^{1 / 2}$ normalized to chondrite composition reported by McDonough and Sun (1995). Literature data are from (a) Coustures et al. (2003), (b) Kř́bek et al. (2016), (c) Leybourne et al. (2006), (d) Baioumy et al. (2017), (e) Halverson et al. (2011), (f) Hu et al. (2020) and (g) Danielson et al. (1992). With few exceptions, hydrothermal-derived gossan have positive Eu anomalies $\left(\mathrm{Eu} / \mathrm{Eu}^{*}{ }_{\text {chondrite }}>1\right)$, whereas sedimentary ores have negative $\mathrm{Eu}$ anomalies $\left(\mathrm{Eu} / \mathrm{Eu}^{*}{ }_{\text {chondrite }}<1\right)$. The positive Eu anomalies in banded iron formations (BIF) reported by Hu et al. (2020) and Danielson et al. (1992) were attributed to hydrothermal Eu inputs in seawater during BIF formation

et al., 2011), it may occur in a single deposit at the inter-layer scale (e.g., Fabre et al., 2011; Johnson et al., 2008; Tsikos et al., 2010), between different minerals (e.g., Frost et al., 2007; Johnson et al., 2003), or in a single mineral (e.g., Czaja et al., 2013; Li et al., 2013; Steinhoefel et al., 2009). Hence, smelting iron ores, in different proportions, from a single marine or supergene sedimentary source with an important Fe isotope variability may have resulted in iron production of heterogeneous $\mathrm{Fe}$ isotope signature, as found for group 3 bars. No ancient iron ore source with elemental and Fe isotopes features similar to these bars, and related to Roman iron production, has been identified so far. Nevertheless, this study suggests that further archaeological surveys may be guided by the hypothesis of a sedimentary iron source.

\section{Unclassified SM2-96-K46 iron bar}

The lack of inclusion of slag in SM2-96-K46 bar prevented the attribution of a provenance group using trace element analysis (Coustures et al., 2006). Except for the marine-corroded sample SM2-96-K46b (Table 2), this iron bar has a homogeneous $\delta^{57} \mathrm{Fe}$ similar to the Montagne Noire ore (Figure 4), suggesting a provenance from this district. In addition, its EROTIS stamp also leads to the conclusion that it was produced in the same smelting workshop as SM2-96-KL31 and SM2-4 bars which were found in the same shipwreck. More than a tool for validating provenance hypotheses, $\mathrm{Fe}$ isotopes may therefore replace slag elemental analyses and enable tracing iron artefacts devoid of slag inclusions. 


\section{Iron production organization in the Montagne Noire district and ore sources determination}

Previous studies on the same semi-products from Les Saintes-Maries-de-la-Mer found differences in major element compositions of slag inclusions between welded pieces of long bars (1L and $2 \mathrm{~L}$ bars). As a result, these authors suggested that the chaine opératoire of iron bars production was geographically segmented between reduction sites and workshops of bars manufacturing (Pagès et al., 2008, 2011). In this model, smithing workshops centralized iron production from different smelting sites located in several districts, inducing circulation of poorly refined iron instead of manufactured iron bars. In contrast, the homogeneous $\delta^{57} \mathrm{Fe}$ of the long bars (group 1) uncovered in the present study rather argues for a single origin for welded pieces. Besides, trace element analyses allow distinguishing the iron productions of several workshops (i.e., also reflected by EROTIS and LEPIDI stamps) (Figure 3), in the same mining district, using the same ore sources - in different proportions - having heterogeneous elemental composition (Béziat et al., 2016b; Coustures et al., 2007). The differences of major elements composition may indeed reflect that of the gossans from the Montagne Noire (Baron et al., 2011; Coustures et al., 2006) or may have been influenced by the temperature and smelting conditions (charcoal and furnace lining) from one reduction batch to another (e.g., Benvenuti et al., 2013, 2016; Béziat et al., 2016a; Paynter, 2006). In the case of a centralized iron bar production, smithing workshops would have been supplied in several pieces of poorly refined metal from several mining districts. Hence, it is highly likely that bars produced in the same smithing workshop (or welded iron pieces from the same bar) would have shown heterogeneous $\delta^{57} \mathrm{Fe}$ and/or trace element ratios of their slag inclusions different from the Montagne Noire, which is not the case here. Combined trace elements and Fe isotopes analyses show that bars from group 1 were smelted and manufactured in the same mining district, here the Montagne Noire (Figures 3 and 4). Furthermore, this is consistent with the archaeological data of the Roman period in this region showing smithing workshops dedicated to iron bars production located near the bloomery furnaces (Fabre et al., 2016).

Associated trace elements and Fe isotopes analyses on the bars from Les-Saintes-Maries-dela-Mer also provide information about the nature of their ore sources. The distinct trace element ratios, positive $\mathrm{Eu}$ anomaly, and similar $\delta^{57} \mathrm{Fe}$ of groups 1 and 2 iron bars are features inherited from their gossan ore source. Comparison with data from the literature supports this inference (Figures 5 and 6). Only few Fe isotope compositions of iron ores are available in the literature so far, although published data have increased in recent years, especially from China. Nevertheless, when comparing the isotopic variability of the bars with that of the different types of iron ore, the narrow $\delta^{57} \mathrm{Fe}$ variability we measured for the bars from groups 1 and 2 was of the same order of magnitude than those previously measured in gossans and hydrothermally derived secondary goethite (Cheng et al., 2015; Milot et al., 2016; Milot, 2016) (Figure 5). The narrow $\delta^{57} \mathrm{Fe}$ range in gossans may seem surprising since it results from oxidative alteration processes. This range is even smaller than that observed in primary Fe minerals of lower oxidation degree from hydrothermal or magmatic systems (e.g., Wang et al., 2011; Gagnevin et al., 2012; Cheng et al., 2015; Günther et al., 2017; Zhao et al., 2019) (Figure 5). This can be explained by the total alteration of isotopically fractionated Fe minerals and a rapid precipitation of Fe oxides without any loss of iron during gossan formation. Hence, the Fe isotope composition of gossans first depends on the mineralogy of primary ore from which they are derived, and it is worthy to note here that Fe sulphides, or sulphide-derived gossans, cannot be used to produce iron as the high $\mathrm{S}$ content in the metal makes it of poor quality. Great variations of $\mathrm{Fe}$ isotope composition were also observed at an intra-mineral scale (e.g., Horn et al., 2006; Markl et al., 2006), but these differences are averaged during metallurgical processes (Milot et al., 2016), and small-scale isotopic variations in ores are not reflected in the iron bars. 
In contrast to groups 1 and 2, the broad $\delta^{57} \mathrm{Fe}$ range and negative Eu anomaly of bars from group 3 rather point to a single source of marine or supergene sedimentary iron ores (Figures 5 and 6). This $\delta^{57} \mathrm{Fe}$ variability is indeed consistent with previously published data since comparable ranges were measured in sedimentary or supergene ores such as BIF from Togo (Milot, 2016), Greenland (Czaja et al., 2013) and Canada (Halverson et al., 2011), iron concretions from the United States (Busigny \& Dauphas, 2007), or bog iron ores from Germany (Rose et al., 2019) (Figure 5). Hence, different reduction batches of ores from the same source having highly variable Fe isotope composition could result in iron products showing within-bar isotopic homogeneity, but distinct Fe isotope composition between bars. In such a case, we note that the sedimentary source of bars from group 3 has an Fe isotope composition range significantly lighter than the Montagne Noire signature, although partly overlapping for SM6-3 and SM9-99-248 bars.

The Tarn department (located to the north-west of the Montagne Noire) hosts numerous iron ore resources of $\mathrm{Fe}$ isotope composition lighter than ores from the Montagne Noire (Figure 5), and which could be compared with the signature of bars from group 3. However, iron ore deposits from the Tarn department are gossans and not sedimentary, and their signature only partly overlaps the total Fe isotope composition range of these bars. They are also archaeological arguments against an ore source located in the Tarn department for group 3 bars. This area is located in the nearby north of the Montagne Noire massif and was intensively exploited for iron during Gallic times. Nevertheless, the peak of this iron production in the second century BCE is older than the oldest bars analysed in this study, and evidence of this Gallic iron trade rather leads to a search of its diffusion area towards the interior of Gaul (Pailler, 2011). A more plausible source for these bars could be the Corbières massif (located south of Montagne Noire massif) whose territory was under Roman administration and which hosted sedimentary iron ores (Mantenant, 2014). The Canigou massif (eastern French Pyrenees, located to the south of Montagne Noire) and the Sierra Menera area (eastern Spain) are also known for ancient iron exploitation and could be the sources of iron bars from Les SaintesMaries-de-la-Mer (Long et al., 2002). Of course, archaeological and geological surveys, as well as geochemical analyses, are needed to validate or reject these hypotheses. Overall, our results illustrate the benefit of combining different geochemical and archaeological approaches for iron metals tracing because it may inform us about the geographical distribution of different steps of the chaine opératoire, the nature of the exploited ores, and could give further directions for the identification of sources.

\section{CONCLUSIONS}

This study of the provenance of iron bars from Les Saintes-Maries-de-la-Mer Roman shipwrecks is the first example of the use of Fe isotopes for ancient iron tracing for a given archaeological context. Previous studies already investigated the ore sources of the same bars by trace element analyses of their slag inclusions (Baron et al., 2011; Coustures et al., 2006). These allowed establishing groups of bars of distinct provenances, sometimes associated with specific shapes and/or stamps. Our results validate the provenance assumptions for most of the bars. Those from groups 1 and 2 are thought to originate from the Montagne Noire district, whereas bars from group 3 come from another district not yet identified, but potentially lying in the Corbières area, the Canigou Massif or the Sierra Menera (Spain), more to the south. In this archaeological context of Roman iron production in the Montagne Noire, the homogeneity of $\mathrm{Fe}$ isotope compositions within each bar confirms the archaeological data showing a nonspatially segmented chaine opératoire of iron bars production.

In addition, this study shows that combining trace elements and Fe isotopes analyses on the same archaeological iron artefacts may provide crucial information about the nature of their 
ore sources. The slag inclusions elemental heterogeneity, positive Eu anomaly and Fe isotope homogeneity of bars from the groups 1 and 2 are inherited from gossan-type iron ore. On the contrary, the constant trace element ratios, the negative $\mathrm{Eu}$ anomaly and heterogeneous $\delta^{57} \mathrm{Fe}$ of group 3 bars suggest a common source consisting of sedimentary iron ores. Although the current database on $\mathrm{Fe}$ isotope compositions of different ore sources in the former Roman world is not yet sufficient to precisely identify the ore origin of bars from group 3, our results may be used to determine their potential sources when combined with archaeological and historical hypotheses. Hence, this work offers many perspectives for iron metals-tracing, even when the metal is slag inclusions-free. It illustrates the importance of combining elemental and isotopic tracing approaches put into an archaeological context to obtain reliable results for provenance studies.

\section{ACKNOWLEDGEMENTS}

The authors thank the Federal University of Toulouse and the Midi-Pyrénées Région for funding Jean Milot's PhD thesis. Sampling and analyses were conducted in CNRS laboratories in Toulouse (TRACES and GET, respectively). Jonathan Prunier and Manuel Henry are thanked for clean room maintenance; and Jérôme Chmeleff for MC-ICP-MS maintenance. The authors thank Alain Ploquin for helpful advice throughout this study. Anne-Marie Desaulty, Claude Domergue, Didier Béziat and Caroline Robion-Brunner are also thanked for discussions about this work. Ryan Mathur and an anonymous referee are also thanked for their thoughtful reviews that helped to sharpen the arguments presented.

\section{OR CID}

Franck Poitrasson (D) https://orcid.org/0000-0003-4097-2771

Sandrine Baron (D) https://orcid.org/0000-0003-1910-8903

\section{REFERENCES}

Artioli, G., Canovaro, C., Nimis, P., \& Angelini, I. (2020). LIA of prehistoric metals in the Central Mediterranean area: A review. Archaeometry, 62, 53-85. https://doi.org/10.1111/arcm.12542

Babechuk, M. G., Widdowson, M., \& Kamber, B. S. (2014). Quantifying chemical weathering intensity and trace element release from two contrasting basalt profiles, Deccan traps, India. Chemical Geology, 363, 56-75. https://doi. org/10.1016/j.chemgeo.2013.10.027

Bachmann, H. G. (1982). The identification of slags from archaeological sites. Occasional Publication 6. The Institute of Archaeology.

Baioumy, H., Omran, M., \& Fabritius, T. (2017). Mineralogy, geochemistry and the origin of high-phosphorus oolitic iron ores of Aswan, Egypt. Ore Geology Reviews, 80, 185-199. https://doi.org/10.1016/j.oregeorev.2016.06.030

Baron, S., Coustures, M.-P., Béziat, D., Guérin, M., Huez, J., \& Robbiola, L. (2011). Lingots de plomb et barres de fer des épaves romaines des Saintes-Maries-de-la-Mer (Bouches-du-Rhône, France): Questions de traçabilité comparée. Revue Archéologique de Narbonnaise, 44, 71-98. https://doi.org/10.3406/ran.2011.1820

Benvenuti, M., Dini, A., D’Orazio, M., Chiarantini, L., Corretti, A., \& Costagliola, P. (2013). The tungsten and tin signature of iron ores from Elba Island (Italy): A tool for provenance studies of iron production in the Mediterranean region. Archaeometry, 55, 479-506. https://doi.org/10.1111/j.1475-4754.2012.00692.x

Benvenuti, M., Orlando, A., Borrini, D., Chiarantini, L., Costagliola, P., Mazzotta, C., \& Rimondi, V. (2016). Experimental smelting of iron ores from Elba Island (Tuscany, Italy): Results and implications for the reconstruction of ancient metallurgical processes and iron provenance. Journal of Archaeological Science, 70, 1-14. https://doi.org/ 10.1016/j.jas.2016.04.008

Bérard, E., Pécheyran, C., Dillmann, P., Leroy, S., Vega, E., Williams, A., Verna, C., \& Toureille, V. (2020). Ancient Armour provenance by LA-ICP-MS analysis of microscopic slag inclusions. Journal of Analytical Atomic Spectrometry, 35(11), 2582-2593. https://doi.org/10.1039/D0JA00259C

Béziat, D., Coustures, M.-P., Dabosi, F., Domergue, C., Leblanc, J. C., \& Tollon, F. (2016b). L'archéométrie des déchets sidérurgiques, in Le fer romain de la Montagne noire, Martys 2: Les débuts, 25 années de recherches pluridisciplinaires (1988-2013) (eds. Fabre, J.-M., Domergue, C. and Dabosi, F.). Supplément à la Revue Archéologique de Narbonnaise, 43, 560.

Béziat, D., Coustures, M.-P., \& Tollon, F. (2016a). Les minerais de fer de la Montagne noire: minéralogie et chimie, quelques éléments de réponse aux questions d'approvisionnement et de traitements minéralurgiques, in Le fer 
romain de la Montagne noire, Martys 2: Les débuts, 25 années de recherches pluridisciplinaires (1988-2013) (eds. Fabre, J.-M., Domergue, C. and Dabosi, F.). Supplément à la Revue Archéologique de Narbonnaise, 43, 560.

Bilenker, L. D., Simon, A. C., Reich, M., Lundstrom, C. C., Gajos, N., Bindeman, I., Barra, F., \& Munizaga, R. (2016). Fe-O stable isotope pairs elucidate a high-temperature origin of Chilean iron oxide-apatite deposits. Geochimica et Cosmochimica Acta, 177, 94-104. https://doi.org/10.1016/j.gca.2016.01.009

Blakelock, E., Martinón-Torres, M., Veldhuijzen, H. A., \& Young, T. (2009). Slag inclusions in iron objects and the quest for provenance: An experiment and a case study. Journal of Archaeological Science, 36, 1745-1757. https:// doi.org/10.1016/j.jas.2009.03.032

Brauns, M., Schwab, R., Gassmann, G., Wieland, G., \& Pernicka, E. (2013). Provenance of iron age iron in southern Germany: A new approach. Journal of Archaeological Science, 40, 841-849. https://doi.org/10.1016/j.jas.2012. 08.044

Brauns, M., Yahalom-Mack, N., Stepanov, I., Sauder, L., Keen, K., \& Eliyahu-Behar, A. (2020). Osmium isotope analysis as an innovative tool for provenancing ancient iron: A systematic approach. PLoS ONE, 15(3), e0229623. https://doi.org/10.1371/journal.pone.0229623

Bullen, T. D., White, A. F., Childs, C. W., Vivit, D. V., \& Schulz, M. S. (2001). Demonstration of significant abiotic iron isotope fractionation in nature. Geology, 29, 699-702. https://doi.org/10.1130/0091-7613(2001)029<0699: DOSAII $>2.0 . \mathrm{CO} ; 2$

Busigny, V., \& Dauphas, N. (2007). Tracing paleofluid circulations using iron isotopes: A study of hematite and goethite concretions from the Navajo sandstone (Utah, USA). Earth and Planetary Science Letters, 254, $272-287$. https://doi.org/10.1016/j.eps1.2006.11.038

Charlton, M. F. (2015). The last frontier in 'sourcing': The hopes, constraints and future for iron provenance research. Journal of Archaeological Science, 56, 210-220. https://doi.org/10.1016/j.jas.2015.02.017

Charlton, M. F., Blakelock, E., Martinon-Torres, M., \& Young, T. (2012). Investigating the production provenance of iron artifacts with multivariate methods. Journal of Archaeological Science, 39, 2280-2293. https://doi.org/10.1016/ j.jas.2012.02.037

Cheng, Y. B., Mao, J. W., Zhu, X. K., \& Wang, Y. (2015). Iron isotope fractionation during supergene weathering process and its application to constrain ore genesis in Gaosong deposit, Gejiu district, SW China. Gondwana Research, 27, 1283-1291. https://doi.org/10.1016/j.gr.2013.12.006

Coustures, M.-P., Béziat, D., Tollon, F., Domergue, C., Long, L., \& Rebiscoul, A. (2003). The use of trace element analysis of entrapped slag inclusions to establish ore-bar links: Examples from two Gallo-Roman iron-making sites in France (les Martys, Montagne noire, and les Ferrys, Loiret). Archaeometry, 45, 599-613. https://doi.org/10. 1046/j.1475-4754.2003.00131.x

Coustures, M. P., Dieudonné-Glad, N., Dillmann, P., \& Béziat, D. (2014). Tentative chemical characterization of a Roman smelting workshop (Oulches, France): From the ore to the finished product. Early Iron in Europe, Montagnac, Editions Monique-Mergoil, Coll. 'Monographies Instrumentum', 50, 93-115.

Coustures, M.-P., Renoux, G., Scaon, C., Béziat, D., Rico, C., Dabosi, F., Long, L., Domergue, C., \& Tollon, F. (2007). Le point Sur Une méthode de détermination de provenance des objets en fer de la sidérurgie ancienne. Aquitania, Supplément, 14(2), 145-150.

Coustures, M.-P., Rico, C., Béziat, D., Djaoui, D., Long, L., Domergue, C., \& Tollon, F. (2006). La provenance des barres de fer romaines des Saintes-Maries-de-la-Mer. Etude archéologique et archéométrique. Gallia, 63, $243-261$. https://doi.org/10.3406/galia.2006.3297

Czaja, A. D., Johnson, C. M., Beard, B. L., Roden, E. E., Li, W., \& Moorbath, S. (2013). Biological Fe oxidation controlled deposition of banded iron formation in the ca. 3770 Ma Isua Supracrustal Belt (West Greenland). Earth and Planetary Science Letters, 363, 192-203. https://doi.org/10.1016/j.eps1.2012.12.025

Danielson, A., Möller, P., \& Dulski, P. (1992). The europium anomalies in banded iron formations and the thermal history of the oceanic crust. Chemical Geology, 97, 89-100. https://doi.org/10.1016/0009-2541(92)90137-T

Dauphas, N., \& Rouxel, O. (2006). Mass spectrometry and natural variations of iron isotopes. Mass Spectrometry Reviews, 25, 515-550. https://doi.org/10.1002/mas.20078

Degryse, P., Schneider, J. C., Kellens, N., Waelkens, M., \& Muchez, P. (2007). Tracing the resources of iron working at ancient Sagalassos (south-west Turkey): Combined lead and strontium isotope study on iron artifacts and ores. Archaeometry, 49, 75-86. https://doi.org/10.1111/j.1475-4754.2007.00288.x

Desaulty, A.-M., Dillmann, P., L'Héritier, M., Mariet, C., Gratuze, B., Joron, J. L., \& Fluzin, P. (2009). Does it come from the pays de bray? Examination of an origin hypothesis for the ferrous reinforcements used in French medieval churches using major and trace element analyses. Journal of Archaeological Science, 36, 2445-2462. https://doi. org/10.1016/j.jas.2009.07.002

Dillmann, P., \& L'Héritier, M. (2007). Slag inclusion analyses for studying ferrous alloys employed in French medieval buildings: Supply of materials and diffusion of smelting processes. Journal of Archaeological Science, 34, 18101823. https://doi.org/10.1016/j.jas.2006.12.022

Dillmann, P., Schwab, R., Bauvais, S., Brauns, M., Disser, A., Leroy, S., Gassmann, G., \& Fluzin, P. (2017). Circulation of iron products in the North-Alpine area during the end of the first iron age (6th-5th c. BC): A combination 
of chemical and isotopic approaches. Journal of Archaeological Science, 87, 108-124. https://doi.org/10.1016/j.jas. 2017.10.002

Disser, A., Dillmann, P., Leroy, M., L’Héritier, M., Bauvais, S., \& Fluzin, P. (2017). Iron supply for the building of Metz cathedral: New methodological development for provenance studies and historical considerations. Archaeometry, 58, 493-510. https://doi.org/10.1111/arcm.12265

Domergue, C., Cauuet, B., Lavielle, E., Pailler, J.-M., Sablayrolles, R., Sillieres, P., \& Tollon, F. (1993). Un Centre sidérurgique romain de la Montagne noire. Le domaine des forges (les Martys, Aude). Supplément à la Revue Archéologique de Narbonnaise, 27, 477.

Fabre, J.-M., Domergue, C., \& Dabosi, F. (2016). Le fer romain de la Montagne noire, Martys 2: Les débuts, 25 années de recherches pluridisciplinaires (1988-2013). Supplément à la Revue Archéologique de Narbonnaise, 43, 560.

Fabre, S., Nedelec, A., Poitrasson, F., Strauss, H., Thomazo, C., \& Nogueira, A. (2011). Iron and Sulphur isotopes from the Carajas mining province (Para, Brazil): Implications for the oxidation of the ocean and the atmosphere across the Archaean-Proterozoic transition. Chemical Geology, 289, 124-139. https://doi.org/10.1016/j.chemgeo. 2011.07.019

Fernandez, A., \& Borrok, D. M. (2009). Fractionation of $\mathrm{cu}, \mathrm{Fe}$, and $\mathrm{Zn}$ isotopes during the oxidative weathering of sulfide-rich rocks. Chemical Geology, 264, 1-12. https://doi.org/10.1016/j.chemgeo.2009.01.024

Frierdich, A. J., Beard, B. L., Reddy, T. R., Scherer, M. M., \& Johnson, C. M. (2014b). Iron isotope fractionation between aqueous $\mathrm{Fe}$ (II) and goethite revisited: New insights based on a multi-direction approach to equilibrium and isotopic exchange rate modification. Geochimica et Cosmochimica Acta, 139, 383-398. https://doi.org/10.1016/ j.gca.2014.05.001

Frierdich, A. J., Beard, B. L., Scherer, M. M., \& Johnson, C. M. (2014a). Determination of the Fe (II)aq-magnetite equilibrium iron isotope fractionation factor using the three-isotope method and a multi-direction approach to equilibrium. Earth and Planetary Science Letters, 391, 77-86. https://doi.org/10.1016/j.epsl.2014.01.032

Frost, C. D., von Blanckenburg, F., Schoenberg, R., Frost, B. R., \& Swapp, S. M. (2007). Preservation of Fe isotope heterogeneities during diagenesis and metamorphism of banded iron formation. Contributions to Mineralogy and Petrology, 153, 211-235. https://doi.org/10.1007/s00410-006-0141-0

Gagnevin, D., Boyce, A. J., Barrie, C. D., Menuge, J. F., \& Blakeman, R. J. (2012). Zn, Fe and S isotope fractionation in a large hydrothermal system. Geochimica et Cosmochimica Acta, 88, 183-198. https://doi.org/10.1016/j.gca. 2012.04.031

Günther, T., Klemd, R., Zhang, X., Horn, I., \& Weyer, S. (2017). In-situ trace element and Fe-isotope studies on magnetite of the volcanic-hosted Zhibo and Chagangnuoer iron ore deposits in the Western Tianshan, NW China. Chemical Geology, 453, 111-127. https://doi.org/10.1016/j.chemgeo.2017.02.001

Halverson, G. P., Poitrasson, F., Hoffman, P. F., Nédélec, A., Montel, J.-M., \& Kirby, J. (2011). Fe isotope and trace element geochemistry of the Neoproterozoic syn-glacial Rapitan iron formation. Earth and Planetary Science Letters, 309, 100-112. https://doi.org/10.1016/j.epsl.2011.06.021

Hendrickson, M., \& Leroy, S. (2020). Sparks and needles: Seeking catalysts of state expansions, a case study of technological interaction at Angkor, Cambodia (9th to 13th centuries CE). Journal of Anthropological Archaeology, 57, 101141. https://doi.org/10.1016/j.jaa.2019.101141

Horn, I., von Blanckenburg, F., Schoenberg, R., Steinhoefel, G., \& Markl, G. (2006). In situ iron isotope ratio determination using UV-femtosecond laser ablation with application to hydrothermal ore formation processes. Geochimica et Cosmochimica Acta, 70, 3677-3688. https://doi.org/10.1016/j.gca.2006.05.002

$\mathrm{Hu}$, J., Wang, H., \& Zhang, L. (2020). A rare earth element and Nd isotopic investigation into the provenance and deposition of the Dahongliutan banded iron formation and associated carbonates, NW China: Implications on Neoproterozoic seawater compositions. Precambrian Research, 342, 105685. https://doi.org/10.1016/j.precamres. 2020.105685

Johnson, C., Beard, B., Klein, C., Beukes, N., \& Roden, E. (2008). Iron isotopes constrain biologic and abiologic processes in banded iron formation genesis. Geochimica et Cosmochimica Acta, 72, 151-169. https://doi.org/10.1016/j. gca.2007.10.013

Johnson, C. M., Beard, B. L., Beukes, N. J., Klein, C., \& O’Leary, J. M. (2003). Ancient geochemical cycling in the earth as inferred from $\mathrm{Fe}$ isotope studies of banded iron formations from the Transvaal craton. Contributions to Mineralogy and Petrology, 144, 523-547. https://doi.org/10.1007/s00410-002-0418-x

Johnson, C. M., Skulan, J. L., Beard, B. L., Sun, H., Nealson, K. H., \& Braterman, P. S. (2002). Isotopic fractionation between Fe (III) and Fe (II) in aqueous solutions. Earth and Planetary Science Letters, 195, 141-153. https://doi. org/10.1016/S0012-821X(01)00581-7

Kato, Y., Yamaguchi, K. E., \& Ohmoto, H. (2006). Rare earth elements in Precambrian banded iron formations: Secular changes of $\mathrm{Ce}$ and $\mathrm{Eu}$ anomalies and evolution of atmospheric oxygen. In Kesler, S.E., and Ohmoto, H., (eds.), evolution of early Earth's atmosphere, hydrosphere, and biosphere-constraints from ore deposits. Geological Society of America Memoirs, 198, 269-289. https://doi.org/10.1130/2006.1198(16)

Kříbek, B., Zachariáš, J., Knésl, I., Míková, J., Mihaljevič, M., Veselovský, F., \& Bamba, O. (2016). Geochemistry, mineralogy, and isotope composition of $\mathrm{Pb}, \mathrm{Zn}$, and $\mathrm{cu}$ in primary ores, gossan and barren ferruginous crust from 
the Perkoa base metal deposit, Burkina Faso. Journal of Geochemical Exploration, 168, 49-64. https://doi.org/10. 1016/j.gexplo.2016.05.007

Leroy, S., Cohen, S. X., Verna, C., Gratuze, B., Tereygeol, F., Fluzin, P., Bertrand, L., \& Dillmann, P. (2012). The medieval iron market in Ariege (France). Multidisciplinary analytical approach and multivariate analyses. Journal of Archaeological Science, 39, 1080-1093. https://doi.org/10.1016/j.jas.2011.11.025

Leroy, S., Hendrickson, M., Bauvais, S., Blanchet, T., Disser, A., Vega, E., \& Delqué-Kolic, E. (2017). The ties that bind: Archaeometallurgical typology of architectural crampons as a method for reconstructing the iron economy of Angkor, Cambodia (10th to 13th c.). Archaeological and Anthropological Sciences, 10, 2137-2157.

Leybourne, M. I., \& Johannesson, K. H. (2008). Rare earth elements (REE) and yttrium in stream waters, stream sediments, and Fe-Mn oxyhydroxides: Fractionation, speciation, and controls over REE + Y patterns in the surface environment. Geochimica et Cosmochimica Acta, 72, 5962-5983. https://doi.org/10.1016/j.gca.2008.09.022

Leybourne, M. I., Peter, J. M., Layton-Matthews, D., Volesky, J., \& Boyle, D. R. (2006). Mobility and fractionation of rare earth elements during supergene weathering and gossan formation and chemical modification of massive sulfide gossan. Geochimica et Cosmochimica Acta, 70, 1097-1112. https://doi.org/10.1016/j.gca.2005.11.003

Li, Y.-L., Konhauser, K. O., Kappler, A., \& Hao, X.-L. (2013). Experimental low-grade alteration of biogenic magnetite indicates microbial involvement in generation of banded iron formations. Earth and Planetary Science Letters, 361, 229-237. https://doi.org/10.1016/j.eps1.2012.10.025

Liss, B., Levy, T. E., \& Day, J. M. D. (2020). Origin of iron production in the eastern Mediterranean: Osmium isotope and highly siderophile element evidence from iron age Jordan. Journal of Archaeological Science, 122, 105227. https://doi.org/10.1016/j.jas.2020.105227

Long, L. (1997). Inventaire des épaves de Camargue, de l'Espiguette au Grand Rhône. Des cargaisons de fer antiques aux gisements du XIXème siècle. Leur contribution à l'étude du paléorivage. In M. Baudat (Ed.), Crau, Alpilles, Camargue, histoire et archéologie, Actes du colloque des 18 et 19 novembre 1995 (Vol. 1997) (pp. 59-113). Groupe archéologique arlésien.

Long, L., Djaoui, D., \& Rico, C. (2005). Lingots et barres de fer: vers une typologie plus complète. In: D.R.A.S.S.M (Ed.). In Bilan Scientifique du Département des Recherches Archéologiques Subaquatiques et sous-marines 2003 (pp. 66-68). Direction du Patrimoine. Sous-direction de l'Archéologie. Ministère de la Culture et de la Communication.

Long, L., Rico, C., \& Domergue, C. (2002). Les épaves antiques de Camargue et le commerce maritime du fer en Méditerranée nord-occidentale (Ier siècle avant J.C.-Ier après J.C.). In L'Africa romana XIV, Sassari 2000 (Vol. 2002, pp. 161-188). Rome: Carocci editore.

Long, L., \& Sintès, C. (2003). Commerce maritime et fluvial aux embouchures du Rhône: le rôle d'Arles dans l'Antiquité. In G. Pascual Berlauga \& J. Pérez Ballester (Eds.), Puertos fluviales antiguos: Ciudad, desarollo e infraestructuras, Actas de las IV Jornadas de arqueología subaquática (pp. 183-201). Valence, 28-30 mars 2001. Valence, Université de Valence: Facultad de Geografía e Historia.

Ma, L., Jin, L., \& Brantley, S. L. (2011). How mineralogy and slope aspect affect REE release and fractionation during shale weathering in the Susquehanna/Shale Hills critical zone observatory. Chemical Geology, 290, 31-49. https:// doi.org/10.1016/j.chemgeo.2011.08.013

Mameli, P., Mongelli, G., Oggiano, G., \& Rovina, D. (2014). First finding of early medieval iron slags in Sardinia (Italy): A geochemical-mineralogical approach to insights into ore provenance and work activity. Archaeometry, 56, 406-430. https://doi.org/10.1111/arcm.12019

Mangin, M. (2004). Le Fer, édition Errance, Paris, collection « Archéologiques », 239.

Mantenant, J. (2014). Montagnes métallifères de Gaule méditerranéenne. Approche archéologique et historique de la production des métaux en Languedoc occidental du début du second âge du Fer à la fin de la période romaine $\left(I V^{\text {ème }}\right.$ s. av. n. è.- $V^{\text {ème }}$ s. de n. è.). Thèse de doctorat, Université de Toulouse, vol. 1, 485.

Markl, G., von Blanckenburg, F., \& Wagner, T. (2006). Iron isotope fractionation during hydrothermal ore deposition and alteration. Geochimica et Cosmochimica Acta, 70, 3011-3030. https://doi.org/10.1016/j.gca.2006.02.028

McDonough, W. F., \& Sun, S. (1995). The composition of the earth. Chemical Geology, 120, 223-253. https://doi.org/ 10.1016/0009-2541(94)00140-4

Milot, J. (2016). Utilisation des isotopes du fer pour le traçage des métaux anciens: développement méthodologique et applications archéologiques. Thèse de doctorat, Université Fédérale de Toulouse, 321.

Milot, J., Poitrasson, F., Baron, S., \& Coustures, M.-P. (2016). Iron isotopes as a potential tool for ancient metals tracing. Journal of Archaeological Science, 76, 9-20. https://doi.org/10.1016/j.jas.2016.10.003

Moeller, K., Schoenberg, R., Grenne, T., Thorseth, I. H., Drost, K., \& Pedersen, R. B. (2014). Comparison of iron isotope variations in modern and Ordovician siliceous Fe oxyhydroxide deposits. Geochimica et Cosmochimica Acta, 126, 422-440. https://doi.org/10.1016/j.gca.2013.11.018

Mulholland, D. S., Poitrasson, F., Shirokova, L. S., Gonzalez, A. G., Pokrovsky, O. S., Boaventura, G. R., \& Vieira, L. C. (2015). Iron isotope fractionation during Fe (II) and Fe (III) adsorption on cyanobacteria. Chemical Geology, 400, 24-33. https://doi.org/10.1016/j.chemgeo.2015.01.017 
Pagès, G., Dillmann, P., Fluzin, P., \& Long, L. (2011). A study of the Roman iron bars of Saintes-Maries-de-la-Mer (Bouches-du-Rhône, France). A proposal for a comprehensive metallographic approach. Journal of Archaeological Science, 38, 1234-1252. https://doi.org/10.1016/j.jas.2010.12.017

Pagès, G., Long, L., Fluzin, F., \& Dillmann, P. (2008). Réseaux de production et standards de commercialisation du fer antique en méditerranée: Les demi-produits des épaves romaines des Saintes-Maries-de-la-Mer (Bouches-duRhône, France). Revue Archéologique de Narbonnaise, 41, 261-283. https://doi.org/10.3406/ran.2008.1194

Pailler, J.-M. (2011). Les Rutènes par les mots et les textes. In P. Gruat, J.-M. Pailler, \& D. Schaad (Eds.), Les Rutènes: du peuple à la cité, de l'indépendance à l'installation dans le cadre romain 150 av. J.-C.-100 ap. J.-C (pp. 89-102). Aquitania.

Paynter, S. (2006). Regional variations in bloomery smelting slag of the iron age and Romano-British periods. Archaeometry, 48(2), 271-292. https://doi.org/10.1111/j.1475-4754.2006.00256.x

Pleiner, R. (2000). Iron in archaeology: The European Bloomery smelters. Archaeologicky Ustav Aver.

Pleiner, R. (2006). Iron in archaeology: Early European blacksmiths. Archaeologicky Ustav Aver.

Poitrasson, F. (2006). On the iron isotope homogeneity level of the continental crust. Chemical Geology, 235, 195-200. https://doi.org/10.1016/j.chemgeo.2006.06.010

Poitrasson, F., \& Freydier, R. (2005). Heavy iron isotope composition of granites determined by high resolution MCICP-MS. Chemical Geology, 222, 132-147. https://doi.org/10.1016/j.chemgeo.2005.07.005

Poitrasson, F., Levasseur, S., \& Teutsch, N. (2005). Significance of iron isotope mineral fractionation in pallasites and iron meteorites for the core-mantle differentiation of terrestrial planets. Earth and Planetary Science Letters, 234, 151-164. https://doi.org/10.1016/j.eps1.2005.02.010

Robb, L. (2013). Introduction to ore-forming processes. John Wiley \& Sons.

Rose, T., Telouk, P., Fiebig, J., Marschall, H. R., \& Klein, S. (2020). Iron and oxygen isotope systematics during corrosion of iron objects: A first approach. Archaeological and Anthropological Sciences, 12, 1-18. https://doi.org/10. 1007/s12520-020-01072-8

Rose, T., Telouk, P., Klein, S., \& Marschall, H. R. (2019). Questioning Fe isotopes as a provenance tool: Insights from bog iron ores and alternative applications in archaeometry. Journal of Archaeological Science, 101, 52-62. https:// doi.org/10.1016/j.jas.2018.11.005

Saunier, G., Pokrovski, G. S., \& Poitrasson, F. (2011). First experimental determination of iron isotope fractionation between hematite and aqueous solution at hydrothermal conditions. Geochimica et Cosmochimica Acta, 75, 66296654. https://doi.org/10.1016/j.gca.2011.08.028

Schwab, R., Heger, D., Höppner, B., \& Pernicka, E. (2006). The provenance of iron artefacts from Manching: A multitechnique approach. Archaeometry, 48, 433-452. https://doi.org/10.1111/j.1475-4754.2006.00265.x

Sossi, P. A., Nebel, O., Anand, M., \& Poitrasson, F. (2016). On the iron isotope composition of Mars and volatile depletion in the terrestrial planets. Earth and Planetary Science Letters, 449, 360-371. https://doi.org/10.1016/j. epsl.2016.05.030

Steinhoefel, G., Horn, I., \& von Blanckenburg, F. (2009). Micro-scale tracing of Fe and Si isotope signatures in banded iron formation using femtosecond laser ablation. Geochimica et Cosmochimica Acta, 73, 5343-5360. https://doi. org/10.1016/j.gca.2009.05.037

Stepanov, I. S., Weeks, L., Franke, K. A., Overlaet, B., Alard, O., Cable, C. M., Al Aali, Y. Y., Boraik, M., Zein, H., \& Grave, P. (2020). The provenance of early iron age ferrous remains from southeastern Arabia. Journal of Archaeological Science, 120, 105192. https://doi.org/10.1016/j.jas.2020.105192

Stephens, J. A., Ducea, M. N., Killick, D. J., \& Ruiz, J. (2021). Use of non-traditional heavy stable isotopes in archaeological research. Journal of Archaeological Science, 127, 105334. https://doi.org/10.1016/j.jas.2021.105334

Sun, J., Zhu, X., Chen, Y., \& Fang, N. (2013). Iron isotopic constraints on the genesis of Bayan obo ore deposit, Inner Mongolia, China. Precambrian Research, 235, 88-106. https://doi.org/10.1016/j.precamres.2013.06.004

Trincherini, P. R., Quarati, P., Barbero, P., Domergue, C., \& Long, L. (2001). Where do the lead ingots of the SaintMarie-de-la-Mer wreck come from? Archaeology compared with physics. Archaeometry, 43, 393-406. https://doi. org/10.1111/1475-4754.00023

Tsikos, H., Matthews, A., Erel, Y., \& Moore, J. M. (2010). Iron isotopes constrain biogeochemical redox cycling of iron and manganese in a Palaeoproterozoic stratified basin. Earth and Planetary Science Letters, 298, 125-134. https:// doi.org/10.1016/j.epsl.2010.07.032

Wang, Y., Zhu, X., \& Cheng, Y. (2015). Fe isotope behaviours during sulfide-dominated skarn-type mineralisation. Journal of Asian Earth Sciences, 103, 374-392. https://doi.org/10.1016/j.jseaes.2014.11.005

Wang, Y., Zhu, X.-K., Mao, J.-W., Li, Z.-H., \& Cheng, Y.-B. (2011). Iron isotope fractionation during skarn-type metallogeny: A case study of Xinqiao cu-S-Fe-au deposit in the middle-lower Yangtze valley. Ore Geology Reviews, 43, 194-202. https://doi.org/10.1016/j.oregeorev.2010.12.004

Wawryk, C. M., \& Foden, J. D. (2015). Fe-isotope fractionation in magmatic-hydrothermal mineral deposits: A case study from the Renison Sn-W deposit, Tasmania. Geochimica et Cosmochimica Acta, 150, 285-298. https://doi. org/10.1016/j.gca.2014.09.044 
Zhao, Y., Xue, C., Liu, S.-A., Mathur, R., Zhao, X., Yang, Y., Dai, J., Man, R., \& Liu, X. (2019). Redox reactions control $\mathrm{cu}$ and $\mathrm{Fe}$ isotope fractionation in a magmatic $\mathrm{Ni}-\mathrm{cu}$ mineralization system. Geochimica et Cosmochimica Acta, 249, 42-58. https://doi.org/10.1016/j.gca.2018.12.039

Zhu, Z.-Y., Jiang, S.-Y., Mathur, R., Cook, N. J., Yang, T., Wang, M., Ma, L., \& Ciobanu, C. L. (2018). Iron isotope behavior during fluid/rock interaction in K-feldspar alteration zone-A model for pyrite in gold deposits from the Jiaodong peninsula, East China. Geochimica et Cosmochimica Acta, 222, 94-116. https://doi.org/10.1016/j.gca. 2017.10.001

How to cite this article: Milot, J., Coustures, M.-P., Poitrasson, F., \& Baron, S. (2021). Investigating the provenance of iron bars from Les Saintes-Maries-de-la-Mer Roman shipwrecks (south-east France) with iron isotopes. Archaeometry, 1-23. https://doi.org/ 10.1111/arcm.12715 